\title{
Convivências e Aprendizados
}

\section{Coexistence and Learning}

- Adilson Citellia

Universidade de São Paulo, Programa de Pós-Graduação em Ciências da Comunicação. São Paulo, SP - Brasil

\author{
A NA CRISTINA SUZTNA ${ }^{\text {b }}$ \\ Loughborough University London, Institute for Media and Creative Industries. Londres, \\ Reino Unido
}

\section{THOMAS TUFTE}

Loughborough University London, Institute for Media and Creative Industries. Londres, Reino Unido

University of the Free State, Department of Communication Science. Bloemfontein Free State, África do Sul

Aprenda com quem pode te ensinar. As experiências daqueles que nos precederam nos nossos "poetas mortos" nos ajudam a caminhar pela vida.

-Walt Whitman. Do Not Let.

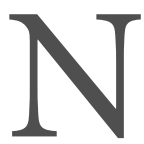

ESTA SEÇÃO DE MATRIZes reservamos espaço para que afetividades, conceitos, reflexões, pudessem livremente manifestar-se acerca de experiências pessoais vividas com Paulo Freire ou mesmo de influências e interlocuções possibilitadas pela obra do patrono da educação brasileira. Publicamos um conjunto de textos, advindos de autores e autoras espalhados por regiões de amplo espectro reunindo Alemanha, Brasil, Dinamarca, Holanda e Filipinas. Tal diversidade de falas, lugares e culturas testemunha a importância do pensamento, assim como dos envolvimentos no trabalho e nas relações pessoais mantidos com Paulo Freire.

Os pronunciamentos múltiplos contam histórias derivadas de situações que evidenciam seja a dimensão humana do mestre ocupado em discutir ideias e dividir afetos, seja o esclarecimento e a realização de projetos cujos resultados alcançaram instituições educativas, departamentos de universidades, linhas de pesquisa, para nos atermos a alguns exemplos. Enfim, os relatos iluminam, por diferentes perspectivas e modalizações, o testemunho de convivências e aprendizados para os quais os procedimentos dialógicos

\footnotetext{
${ }^{a}$ Professor titular no

Departamento de Comunicações e Artes e do Programa de Pós-Graduação em Ciências da Comunicação da Universidade de São Paulo. É coordenador do Grupo de Pesquisa MECOM e bolsista 1B do CNPq. Orcid: https://orcid. org/0000-0002-0838-9917. E-mail: citelli@uol.com.br

${ }^{\mathrm{b}}$ Professora e pesquisadora do Institute for Media and Creative Industries da Loughborough University London. Editora do livro The Evolution of Popular Communication in Latin America (Palgrave, 2021). Orcid: https://orcid.org/00000003-3559-6513. E-mail: a.suzina@lboro.ac.uk
}

${ }^{\mathrm{c}}$ Diretor do Institute for Media and Creative Industries da Loughborough University London e professor extraordinário da University of The Free State, África do Sul. É membro da Academia Europaea. Orcid: https://orcid. org/0000-0003-3253-8481.

E-mail: t.tufte@lboro.ac.uk 
${ }^{\mathrm{d}}$ Este texto é parte de um artigo cuja primeira versão foi publicada em Saul (2017).

e Doutora em Educação e professora titular da Pontifícia Universidade Católica de São Paulo (PUCSP). Coordena a Cátedra Paulo Freire da PUCSP no Programa de Pós-Graduação em Educação. Orcid: https://orcid.org/00000002-0114-444X. E-mail: anasaul@uol.com.br e intercomunicativos, tão defendidos por Paulo Freire, ocupam lugar fundamental. Na presente circunstância histórica atravessada pelas forças do atraso, da intolerância e do autoritarismo, consoante o propósito primário de naturalizar as desigualdades sociais e o intento de promover o monólogo neoliberal como uma espécie de novo sentido do mundo, é preciso ouvir as alocuções da diversidade, pois elas nos ajudam a deslindar o amplo projeto freiriano voltado à emancipação dos seres humanos.

\section{O QUE APRENDI COM PAULO FREIRE ${ }^{\mathrm{D}}$}

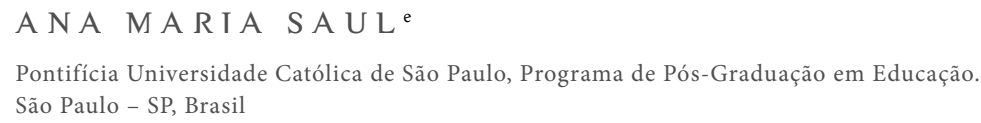

Poucas são as linhas de um texto para dizer do muito que aprendi com Paulo Freire. Costumo sintetizar a minha vivência de trabalho com Paulo Freire, enquanto professor e gestor de uma rede pública de educação como um grande aprendizado de política, de teoria e de prática. Porém, mais do que um grande aprendizado, havia o privilégio de aprender lições de vida com um homem que surpreendia, especialmente pela sua coerência. Paulo Freire foi professor da Pontifícia Universidade Católica de São Paulo (PUCSP), no Programa de Pós-Graduação: Educação (Currículo), depois de sua volta do exílio, pelo período de 17 anos (1980-1997). Tive a grande felicidade de partilhar com ele, pelo período de quase duas décadas, o espaço da sala de aula, dirigindo os seminários das terças-feiras à tarde e por isso posso testemunhar a coerência entre o seu fazer docente, originado de sua reflexão sobre sua prática, e o diálogo constante, que manteve com educadores e educandos de diferentes países do mundo, e as suas proposições político-pedagógicas. Em 1979 tive a chance de ver Paulo Freire ser recebido no teatro da PUCSP, quando ele retornou do exílio. Passei a trabalhar com o professor em 1980, convidado que foi pela instituição para ministrar aulas no Programa de Pós-Graduação: Educação (Currículo).

O Programa de Pós-Graduação onde trabalhávamos, passou por uma reformulação, propondo seminários para orientar a pesquisa dos alunos. Paulo Freire e eu fomos incumbidos de coordenar os seminários, em conjunto. Tínhamos um contato semanal em sala de aula, partilhando a docência e nos encontrávamos, também, em reuniões do Programa e em momentos de planejamento dos seminários. Para o planejamento dos seminários, Paulo Freire costumava "me chamar" 
para um almoço ou um café em sua casa; depois "partíamos", como dizia ele, para fazer o planejamento. Ele procurava sempre ouvir o que eu estava pensando em relação ao próximo semestre, dialogávamos bastante e chegávamos às propostas. Ele fazia questão de ressaltar que os nossos desejos, os nossos sonhos de professores, seriam confrontados com os sonhos dos alunos e por isso propunha que a primeira coisa que faríamos em sala de aula seria discutir a proposta de trabalho dos seminários com os alunos. Considerávamos, para a elaboração do plano, as expectativas dos alunos, as possibilidades de tratamento da temática e as avaliações dos semestres anteriores feitas pelos participantes do seminário. Procurávamos nesses encontros preparatórios, dialogar sobre os nossos desejos, os nossos sonhos, de professores. Esses diálogos com Paulo Freire sempre foram muito produtivos, ricos e fraternos.

No primeiro dia de aula ele se preocupava inicialmente em ouvir os alunos para que as suas necessidades e expectativas estivessem contempladas na proposta de trabalho a ser desenvolvida no semestre. Isso era feito numa sala de aula arrumada em círculo, ambiente propício ao diálogo, onde todos os participantes podiam se ver face a face e onde Paulo Freire podia tocar alguns dos participantes da roda, que estavam a sua direita ou a sua esquerda, colocando delicadamente a mão sobre seus ombros; fazia isto em alguns momentos, num gesto muito espontâneo, como se quisesse ser melhor entendido ou, ainda, para chamar o seu interlocutor à participação. Quem conviveu com Paulo Freire e teve a oportunidade de estar mais perto dele, seguramente, vai se lembrar da expressividade dos seus gestos. Ele era um homem que falava com as mãos. Na condução do trabalho de sala de aula, Paulo Freire fazia questão de estimular os alunos a falar sobre seus projetos, ainda que esses não estivessem detalhados ou totalmente claros. A partir desse relato, ou intenções de pesquisa, passava-se a um segundo momento em que se trabalhava com as diferentes temáticas, encontrando-se os eixos importantes e os fios comuns entre os projetos. De um modo recorrente nas análises, surgiam, com prioridade, os seguintes conceitos: justiça social, poder, liberdade, democracia, utopia, ética, construção do conhecimento, compromisso social, formação do educador, educação como ato político, leitura da realidade, valores do ser humano. A presença de Paulo Freire na sala de aula sempre foi muito querida, marcante e significativa. A sua atuação na aula era discreta. Apesar de ele saber que a sua palavra fazia diferença, com humildade autêntica, raramente era o primeiro a falar. Exercitava, assim, um dos saberes que em seu último livro apontou como necessários à prática educativa: saber escutar. Ouvia a todos atenta e respeitosamente e ficava à vontade para interferir, sempre que julgasse oportuno, ou quando alguém do grupo a ele se dirigia. Nesses momentos, ouvíamos sua voz mansa que revelava, porém, uma postura forte que convidava 
a pensar sobre os desafios por ele apresentados, na direção de uma leitura crítica do mundo, na defesa intransigente da ética do ser humano e da luta a favor dos oprimidos. Os encontros com Paulo Freire sempre foram reflexivos, interessantes, fraternos e surpreendentes. Era admirável a sua clareza de análise do mundo! Inquieto e instigante, buscava sempre a coerência entre sua prática e seu pensamento, mostrando-se indignado com as injustiças sociais. Revelava sempre, no entanto, coragem, humildade e esperança.

A grande oportunidade que tive de conviver e aprender com Paulo Freire, na Universidade, ampliou-se e aprofundou-se quando fui por ele convidada para dirigir a reorientação curricular da Secretaria Municipal de Educação do Município de São Paulo e coordenar o programa de formação permanente dos educadores. Trabalhar na equipe Paulo Freire, enquanto Secretário da Educação, foi uma experiência inusitada. Em nossos encontros de quase todas as manhãs, no seu gabinete, em um edifício da Avenida Paulista, eu encontrava um homem alto, elegante, de terno e gravata, cabelos brancos, quase sempre longos, com suaves ondulações sobre os ombros. Bem-disposto, chegava com pontualidade nas primeiras horas da manhã. Mostrava a sua preocupação com os aspectos mais gerais da política educacional. Surpreendia-me, entretanto, o modo criativo e concreto com que ele tratava o cotidiano. Com a experiência dos seus setenta anos e com a autoridade de um saber, reconhecido por muitos povos do mundo, tinha sempre algo novo a propor, na perspectiva de colocar em prática os princípios da política educacional anunciados em sua gestão, avançando passo a passo, rumo à construção de uma escola pública, popular e democrática.

Experimentei com Paulo Freire o verdadeiro sentido do que é participação. Muito ao contrário da falsa participação que manipula colaboradores, centralizando todas as decisões nas mãos do chefe e delegando apenas a execução de tarefas, a participação na equipe de Paulo Freire assumiu o mais radical dos significados, caracterizando-se verdadeiramente como uma participação em nível político. Isto significou, efetivamente, compartilhar decisões. No cotidiano difícil, demandante, desafiador da educação na cidade de São Paulo, na construção de uma gestão democrática, pude experimentar com Paulo Freire a sua disposição para o diálogo, a demonstração de sua tolerância, uma paciência/ impaciente e um toque de paixão em tudo o que ele fazia.

Quando Paulo Freire já não estava entre nós, em sua homenagem, a PUCSP criou, no $2^{\circ}$ semestre de 1998, a Cátedra Paulo Freire, sob a direção do Programa de Pós-Graduação em Educação: Currículo. Na PUCSP, temos entendido a Cátedra como um espaço para o desenvolvimento de estudos e pesquisas sobre e a partir da obra de Paulo Freire, focalizando as suas repercussões teórico-práticas na área da 
educação e a potencialidade de a pedagogia freiriana fecundar novos pensamentos. Em outras palavras, homenageamos Paulo Freire do jeito que entendemos que ele gostaria de ser homenageado, estudando com rigorosidade o seu pensamento, para compreendê-lo e para recriá-lo. A Cátedra vem desenvolvendo uma ampla pesquisa cumulativa que busca mapear e analisar a "Presença do Pensamento de Paulo Freire nos Sistemas de Educação, no Brasil, a Partir da Década de 90”. Os resultados desta pesquisa têm sido registrados em publicações, com o objetivo de sistematizar e adensar informações que possam subsidiar pesquisadores e gestores de políticas públicas de educação, na perspectiva crítico-emancipadora, possibilitando-lhes analisar e recriar políticas e práticas.

Paulo Freire deixa saudades pela sua lucidez de interpretação dos fatos do mundo, pelo seu poder de indignação, por seu contagiante amor à vida e ao ser humano, por sua luta incessante pela justiça, pela liberdade e por sua presença solidária e sempre amiga.

\section{A MEMÓRIA É O OUTRO EM NÓS: CENTENÁRIO PAULO FREIRE}

A NGELO BRÁS FERNANDES CALLOU

Universidade Federal Rural de Pernambuco, Departamento de Educação. Recife - PE, Brasil

Toda comemoração é um trabalho da memória. Sem memória, perdemos muito da nossa humanidade. Sem ela, não há sociedade, nem história. Um homem sem memória, por contingência ideológica ou física, é um homem em franco processo de alienação e mortificação.

Com o advento do centenário de nascimento de Paulo Freire, comecei a vasculhar na memória tudo o que tinha pensado-escrito sobre o educador pernambucano. Havia uma motivação: a edição do livro Travessias Acadêmicas das Tecnologias de Comunicação para o Desenvolvimento, organizado pela professora Salett Tauk e por mim (Tauk \& Callou, 2019), em comemoração aos nossos 35 anos de atividade docente, na Universidade Federal Rural de Pernambuco (UFRPE). Quando nos debruçamos sobre os nossos baús acadêmicos para catalogar todo o material de pesquisa desenvolvido com os nossos ex-alunos de pós-graduação, encontrei, nos meus arquivos, a transcrição original de uma palestra de Paulo Freire, realizada em Santa Maria, em 1982, a qual tive a oportunidade de assisti-la. A transcrição foi feita pela jornalista e amiga Néri Pedroso. Por certo instinto acadêmico, nunca gostei de me desfazer de documentos, mesmo aqueles aparentemente sem importância, na crença de que, um dia, poderiam construir novos sentidos. E, de fato, foi o que aconteceu.
${ }^{\mathrm{f}}$ Professor titular no

Departamento de Educação da Universidade Federal Rural de Pernambuco (UFRPE). Possui pós-doutorado em História e Cinema, pela Universidade Nova de Lisboa. Orcid: https:// orcid.org/0000-0003-3360-5260. E-mail: angelo.callou@ufrpe.br 
Ao ler a palestra, nos defrontávamos a cada trecho com a atualidade da abordagem do tema - A Educação como Espanto -, e decidimos publicá-la na íntegra, incluindo as respostas de Paulo Freire às perguntas formuladas pela plateia. Era o fio condutor que procurávamos para dar sentido ao vasto material que possuíamos, 80 relatos de pesquisas de 111 autores, na perspectiva de sistematizar as diferentes apropriações teóricas que realizamos para renovar o objeto da Comunicação Rural, da Extensão Rural e da Extensão Pesqueira no Brasil. Professora Nita Freire, viúva de Paulo Freire, foi generosa conosco ao atestar o ineditismo do material e a nos confiar a sua publicação e a escolha do título da palestra. Graças a essa reconstrução da memória, tivemos a comovente constatação da presença marcante do pensamento freiriano na nossa produção docente-discente, ao longo de décadas de trabalho acadêmico.

O primeiro contato que tive com a obra de Paulo Freire foi por mero acaso, tal como afirma Paul Veyne (1998), em Como se Escreve a História, no sentido de que debaixo da lua tudo é devir, acontecimento e acaso. Era 1977. Caiu em minhas mãos a $4^{\text {a }}$ edição do livro Ação Cultural para a Liberdade (Freire, 1976/2013a), publicado originalmente em 1976. Lembro-me perfeitamente desse momento, principalmente pela crítica refinada e fulminante de Paulo Freire às cartilhas de alfabetização. Quando li seus comentários sobre as seguintes frases - "Eva viu a uva", a "Asa é da ave", "Ada deu o dedo ao urubu" -, por exemplo, fui tomado de espanto, para usar uma expressão dele próprio, uma vez que essas frases me eram muito familiares, pois fui alfabetizado numa dessas cartilhas, na escola pública em que estudei.

A leitura de Ação Cultural para a Liberdade (1976/2013a) abriu um universo novo na minha formação universitária, agora menos ingênuo, mais crítico, talvez, e, portanto, mais politizado, para novos desafios. Tornei-me, àquela altura, um leitor assíduo dos livros de Paulo Freire, até o meu encontro com o livrinho, como ele mesmo um dia se referiu à obra Extensão ou Comunicação? (Freire, 1969/2013b). As visões iam se clareando, como diz o poeta, até que um dia acordei professor de Extensão Rural, de Extensão Pesqueira e de Teoria da Comunicação (na pós-graduação) na UFRPE.

O acesso à Extensão ou Comunicação? (Freire, 1969/2013b) tem uma história, no mínimo, curiosa. Foi também por um acaso do destino que me defrontei com este livro, na memorável Livraria Livro 7, no Recife, em 1979, pois assim está grafado no exemplar que guardo com estima até hoje. À época, imaginava como seria interessante se Paulo Freire tivesse escrito sobre Extensão Rural, tal era a minha vontade de seguir carreira nesse campo das Ciências Agrárias. Lia tudo que tivesse relação com o assunto. Fui tomado novamente de espanto ao ver o meu obscuro objeto do desejo materializado sobre um daqueles expositores 
quadrados que compunham aquela imensa livraria. Jamais acreditei em forças de atração dessa natureza. Mas Hermann Hesse garante que tais realizações são possíveis, a exemplo do personagem principal do livro Demian (Hesse, 1919/2012). Seja como for, o livrinho me acompanhou, literalmente, nos momentos mais decisivos da minha vida profissional (concurso para professor, defesas de mestrado e doutorado etc.). Uma espécie de mascote, anjo da guarda, tamanha a importância que teve na minha formação universitária, que o acaso me presenteou.

Recentemente, lendo a biografia de Paulo Freire, escrita por Nita Freire (2017) - Paulo Freire, Uma História de Vida -, percebo um aspecto relevante do enfrentamento de uma geração para ter acesso à escola. A mãe de Paulo Freire, sem condições de colocá-lo numa escola privada, percorreu, em vão, vários colégios públicos do Recife, para matricular no curso secundário o futuro Patrono da Educação Brasileira. Minha mãe era da geração de Paulo Freire. Igualmente, sofreu a mesma saga, em Salvador, pelas mãos de uma migrante espanhola. Histórias que se cruzam.

Paulo Freire, entretanto, teve a sorte de bater à porta de uma instituição privada humanista, o Colégio Oswaldo Cruz, considerado, à época, uma das melhores escolas do Brasil. O proprietário e diretor da instituição, professor Aloízio Pessoa de Araújo, pai de Nita Freire, acolheu o jovem estudante, com uma bolsa de estudo. Professor Aloízio e sua mulher, Genove, eram pessoas reconhecidamente comprometidas com a educação de jovens no Recife. Minha mãe chegou a conhecê-los, por ironia do destino. E uma prima morou com a família durante dois anos, na rua da Soledade, para estudar em um dos colégios próximos dali, em meados dos anos 1960.

Essas passagens, de caráter muito pessoal, e com elas faço a minha pequena homenagem a Paulo Freire, é para dizer que memórias, se alguma serventia há, é justamente a humildade de reconhecer o melhor de nós, a partir do outro. Nisto, Paulo Freire ocupa um lugar central. E imorredouro!

\section{FALANDO POR SI MESMOS, ENCONTRANDO O CAMINHO PARA SEGUIR EM FRENTE JUNTOS: QUANDO A COMUNIDADE ASSUME O COMANDO}

\section{BIRGITTE J A L LOV' \\ EMPOWERHOUSE. Gudhjem, Dinamarca}

Como uma jovem ativista no movimento feminista em Copenhague, nossos Redstocking basis groups se reuniam todas as semanas, buscando crescer pessoal
${ }^{\mathrm{g}}$ Diretora da

EMPOWERHOUSE (https:// empowerhouse.dk/),

organização de apoio a rádios comunitárias para a mudança. Atuou no desenvolvimento de mídia comunitária em países da África, Ásia, Europa e Oriente Médio. Orcid: https://orcid. org/0000-0003-2372-9702. E-mail: birgitte.jallov@mail.dk 
e profissionalmente a partir de um simples - e abrangente - ativismo feminista. Com base em nossa verdade fundamental de "tornar o pessoal político", trabalhamos sistematicamente quando nos encontrávamos, nos revezando em compartilhar o momento em que estávamos em nossas vidas, explorando coletivamente, refletindo, entendendo. Nossas experiências pessoais como mulheres na Dinamarca, nos anos 1970, eram o alicerce, e a partir de nossas experiências individuais coletivizadas, obtínhamos uma compreensão de nossas vidas e por meio desse crescente processo de conscientização, produzíamos sentido de nós mesmas, de nossas vidas e da sociedade em que vivíamos - desenvolvendo de maneira coletiva estratégias e mapas para o caminho a seguir.

Em 1982, quando estagiava em Washington DC, no Women's Institute for Freedom of the Press, um think tank feminista dedicado à mídia, situado nessa cidade, um dos três princípios do Instituto para o jornalismo feminista era que "as mulheres têm que falar por si mesmas". Isso ressoava profundamente com a minha história vivida no movimento, e tornou-se um dos meus mantras pessoais e profissionais, e o núcleo das metodologias de trabalho participativo que se tornaram, junto com minha práxis, partes da minha caixa de ferramentas: "Mulheres - pessoas - devem falar por si mesmas".

Em 1983, ao fazer parte do grupo que fundou a primeira rádio feminista da Dinamarca - Women's Waves -, transformamos os métodos de trabalho dos grupos de base em princípios jornalísticos feministas, usando a nova plataforma conquistada para contar histórias de maneiras não veiculadas em outros lugares na época, construindo novos entendimentos entre as produtoras, as convidadas e as ouvintes. Esse trabalho veio em parte da minha dissertação de mestrado sobre como usar o rádio como ferramenta libertadora para a conscientização feminista: A Counter-Image in Sound (Jallov, 1982), na qual teorias foram adicionadas à minha experiência básica real, a partir do pensamento da Escola de Frankfurt com sua Fantasia Sociológica (Negt, 1971) - e, não menos importante, o universo da teoria da libertação e do pensamento, mediante a percepção encontrada na prática reflexiva de Paulo Freire. Com esse pensamento sistematizado, minha práxis florescente encontrou um lar junto com minha outra estrela guia, representada pela Declaração Universal dos Direitos Humanos.

Nos trinta anos seguintes, continuei testemunhando o poder e a produção do empoderamento, quando todas as pessoas falam por si mesmas e o compartilhamento coletivo e a extração de experiências ajudam a dar sentido ao mundo e a seguir em frente. Esse tem sido o centro do meu trabalho para ajudar as comunidades a construir sua própria mídia, e vem à tona nas histórias de mudança a seguir, ocorridas em Moçambique e no Laos, onde as comunidades têm sido apoiadas para criar a própria estação de rádio da comunidade. 
Paulo Freire e o empoderamento comunitário

Em 196S, Paulo Freire (1970a) escreveu sua inspirada e inspiradora Pedagogia do Oprimido, e expressou em palavras muito do trabalho igualmente importante realizado em sua América Latina natal, incluindo a teologia da libertação. Acreditando no poder da consciencialização como o primeiro passo em um desenvolvimento orientado pelas pessoas, seu pensamento e sua ação possuem muitas semelhanças com o pensamento em torno do empoderamento na minha própria prática ${ }^{1}$. Quatro aspectos do pensamento de Freire vêm à mente, em particular:

(i) a relevância do diálogo, com foco na importância do espaço para a experiência e o conhecimento comunitário e individual, em oposição à instrução de cima para baixo, que Freire chamou de bancária;

(ii) a práxis, ou seja, ação que é informada e baseada em um valor, com o objetivo de criar mudanças. O objetivo é uma comunidade aprimorada e a construção de capital social para facilitar a justiça e o desenvolvimento humano;

(iii) Pedagogia do oprimido ou pedagogia da esperança, que chama a atenção para aqueles que não têm voz e que são oprimidos. Um elemento importante disso foi sua preocupação com a conscientização, desenvolvendo a consciência para ter o poder de transformar a realidade; $\mathrm{e}$

(iv) a necessidade de se basear na experiência vivida dos participantes, pois isso torna o aprendizado/empoderamento possível. Basear-se nas coisas que são entendidas e conhecidas abre a mente para novas percepções.

\section{ABRINDO COMUNIDADES, CORAÇÕES E MENTES - E OPÇÕES DE DESENVOLVIMENTO - POR MEIO DO DIÁLOGO NO LAOS}

Em 2006, o Ministério da Informação do Laos juntamente com o Programa das Nações Unidas para o Desenvolvimento (PNUD) decidiu fazer um projeto piloto, começando uma rádio comunitária em Khoun, na província de Xieng Khuoang. Era uma das áreas do Laos mais atingidas pela guerra secreta de mais de 15 anos, durante a qual duas toneladas de bombas por habitante foram lançadas sobre as belas montanhas e plantações de arroz (O’Connor, 2020). Reconstruída, Khoun é agora um pequeno distrito na província de Lao Xieng Khouang, e um dos 47 distritos mais pobres do Laos. Os desafios de desenvolvimento são imensos para as 90 aldeias com mais de 31 mil pessoas: 40,6\% são de etnia lao lum, 54,14\% são hmong e 5,22\% são khamu. De acordo com o censo de 2005, um terço das pessoas do distrito não tinha acesso às estradas naquela época, e dois terços não tinham eletricidade. Oitenta e dois centros de saúde existiam no distrito, e em 2000, os profissionais de saúde qualificados na província de Xieng Khuoang participaram de apenas $8 \%$ dos nascimentos. A taxa de analfabetismo era de $25 \%$ dos adultos no distrito de Khoun. Uma maioria de dois terços é de mulheres étnicas, e são o grupo mais vulnerável. 
${ }^{2}$ A avaliação do impacto foi realizada março de 2009 , como referido em Jallov (2014).
Com os lao lum vivendo nos vales, os khmu a meio caminho das montanhas e o hmong nas regiões mais altas, os três grupos étnicos do distrito tinham pouca interação, devido à falta de infraestrutura, mas também às muitas contradições políticas, históricas e conflitos desde a última guerra, e com os lao lum dominando os outros. Foi nessa realidade que se iniciou a Rádio Comunitária Khoun para o Desenvolvimento.

A decisão foi tomada porque os desafios de desenvolvimento nos distritos mais pobres não pareciam arrefecer, apesar dos intensos esforços ao longo de muitos anos. Com um estado unipartidário, no qual as vozes dos cidadãos não têm um espaço regular na rádio nacional, o governo do Laos reconheceu que algo era necessário para que a dinâmica de desenvolvimento fosse estimulada nessas pequenas comunidades étnicas nas regiões montanhosas do país. Esse foi o início da emissora comunitária.

Um ano após a Rádio Comunitária Khoun para o Desenvolvimento ter iniciado suas atividades, uma avaliação de impacto foi realizada, para ver se a hipótese de que uma rádio comunitária estimularia o desenvolvimento, realmente tinha funcionado. Apenas um ano depois da rádio ter começado, com os desafios habituais cumpridos e resolvidos, o desenvolvimento, de fato, começou a ganhar ritmo, incluindo ${ }^{2}$ :

- maior harmonia e igualdade nas famílias, e práticas menos abusivas direcionadas às mulheres;

- 60-70\% mais mulheres étnicas usavam serviços de saúde quando grávidas;

- 50\% mais mulheres étnicas vacinaram seus filhos;

- importante diminuição das doenças relacionadas à diarreia, devido à melhoria em práticas;

- os pais começaram a assumir mais responsabilidade pelo bem-estar das crianças (o que antes era deixado para a escola);

- novas técnicas agrícolas foram demonstradas e adotadas - com resultados positivos:

Com a Rádio Khoun podemos saber coisas que não sabíamos antes. A Rádio Khoun fala sobre coisas que estão próximas de nós. Podemos ir ver o que ouvimos. Isso gera confiança! (Homem hmong adulto)

No interior do coletivo de 80 emissoras voluntárias Khoun, as seguintes declarações de impacto foram compartilhadas com base na questão: como eles viram seu papel no processo de desenvolvimento?

Antes da Rádio Khoun, nosso povo não tinha informações locais em nossa própria língua. Estou feliz por fazer parte disso. Minha família está muito orgulhosa por eu ajudar nosso povo! E isso ajuda muito!!! (Homem $\mathrm{khmu}$ ) 
Aprendi muito na rádio: fazer pesquisa para um programa, analisar nossos problemas, entrevistar pessoas, montar o programa semanal, trabalhar com edição de computador... Um monte de novas habilidades importantes - é realmente emocionante!!! Trabalhar com colegas e amigos de outros grupos étnicos também é novo. Nós nos respeitamos e trabalhamos bem juntos. A começar por nós, os produtores, a rádio tem o potencial de ser uma ferramenta realmente importante para a união de toda a nossa comunidade khoun. (Mulher jovem lao lum)

Essas mudanças inovadoras aconteceram lentamente à medida que o tecido social fraturado estava se recompondo por meio do diálogo e do entendimento que se fortaleciam. A estrutura da rádio comunitária, favorecendo o espaço para a criação da comunidade e a experiência individual do outro, gerou a base da unidade, como disse a mulher antes. Ao contrário da educação de cima para baixo, que Freire chamava de bancária.

\section{Comunidades empoderadas assumem o comando de mudanças positivas no centro de Moçambique}

Saindo de uma guerra civil de 30 anos (parcialmente imposta externamente) e de um período de 25 anos de imprensa controlada pelo governo socialista de partido único, Moçambique com o acordo de paz em 1992, passou a considerar a mídia ${ }^{3}$ para apoiar a reconstrução do país rumo a uma democracia multipartidária. Entre as oportunidades analisadas por Moçambique e seus parceiros de desenvolvimento, se cogitava, também como uma novidade, colocar a mídia nas mãos das comunidades, cujas vozes nunca tinham sido ouvidas dessa forma.

Com quatro rádios comunitárias controladas pelo estado, herdadas do período socialista, uma das quais católica, as demais dirigidas pelo Estado, parceiros como a Organização das Nações Unidas para a Educação, a Ciência e a Cultura (UNESCO), o PNUD, a Igreja Católica e o Instituto de Comunicação Social do Governo (ICS) (https://www.ics.gov.mz/) uniram-se para explorar oportunidades para dar início a um movimento de apoio às comunidades, formar rádios de propriedade comunitária, desenvolvendo programas de rádio elaborados por membros voluntários da comunidade sobre questões importantes em suas vidas (Jallov, 2015).

Iniciando o movimento em 2000, 30 estações puderam ser identificadas em 2002, 50 em 2004 e hoje, em 2021, há mais de 100 estações de mídia comunitárias em Moçambique, com diferentes estruturas de propriedade e orientação. Como o artigo histórico citado descreve, mais da metade das estações criadas eram estações comunitárias reais, não de propriedade e controladas pelo Estado
${ }^{3}$ Primeira lei nesse sentido aprovada - já em 1991 (Lei $\mathrm{n}^{\circ} 18 / 91$, de 10 de agosto de 1991) - um ano antes do acordo de paz e logo após a nova Constituição. 
${ }^{4}$ Uma experiência pessoal da autora desse artigo, que viveu e trabalhou em Moçambique entre 1998-2004 (http://www. mediamoz.com/). ou uma igreja, mas pela própria comunidade. O significado e o impacto dessas estações em Moçambique estão documentados, e os achados ressaltam tudo o que a Pedagogia do Oprimido de Freire significa, chamando atenção para aqueles que não têm voz, e que são oprimidos.

Em Moçambique, em muitas comunidades, o espírito comunitário e o tecido social foram destruídos após a trágica e dura guerra civil, na qual linhas de tensão foram criadas entre as aldeias e famílias, nas quais alguns de um lado feriram alguns do outro lado. Isso provocou paralisia e imobilidade, também de desenvolvimento. Quando as rádios comunitárias começaram a ser criadas por meio da facilitação, mobilização comunitária e empoderamento, as comunidades mudaram, deixando de ser objetos movidos por outros, para se tornarem sujeitos de seu próprio destino, coletivamente. Um parlamentar sênior, voltando à capital Maputo após uma visita a sua aldeia, um ano depois de a comunidade ter começado uma estação de rádio, foi surpreendido pela energia local, dinamismo e ação empoderada que havia testemunhado: "Vidas totalmente transformadas na minha aldeia de infância - como uma rádio comunitária pode causar isso???"4

O envolvimento sistemático dos membros da comunidade em grupos editoriais sobre assuntos de interesse (educação, cultura, saúde, direitos...), com base na efetiva mobilização, mapeamento comunitário e capacitação, gera a conscientização de que fala Freire, o conhecimento intuitivo sobre a capacidade de - por meio dos conhecimentos - transformar a realidade. O capital social adicionado gerou, a partir do trabalho colaborativo e orientado para o futuro na rádio (ao contrário da paralisia do passado), novas e produtivas aberturas e oportunidades.

Em um ano, no qual os participantes locais com suporte técnico mobilizaram, inspiraram e treinaram membros da comunidade para liderar e ocupar a rádio comunitária na capital do distrito de Dondo, na província de Sofala, na região central de Moçambique, foram percebidos os seguintes resultados de impacto - incluindo a mudança mais geral em termos de abertura, aumento do debate, da autonomia e melhoria dos meios de subsistência:

- As mulheres passaram a ser mais respeitadas, com mais interesse em cargos eletivos - e muito menos violência contra elas;

- Fornecimento de eletricidade (havia sido interrompido devido a práticas desonestas);

- Policiamento comunitário (diminuindo os roubos e a violência);

- Fim das mortes por cólera (média normal de 160-200 por ano, durante a estação chuvosa);

- Melhores serviços públicos em hospitais e consultórios (a rádio comentava quando os funcionários não apareciam no trabalho); 
- Mais testes de HIV/AIDS (devido à maior abertura e desestigmatização);

- Aumento da participação nas eleições (por causa de informações compreensíveis e encorajamento);

- Maior orgulho a respeito da cultura e da linguagem local (uma razão importante pela qual a rádio era tão confiável).

\section{Com a confiança no centro da mudança comunitária}

Com a origem ativista dos meus métodos de trabalho, focados no empoderamento e sistematização freiriana, as metodologias que cocriei no início de emissoras de rádio e mídias comunitárias deram evidências adicionais ao poder de construir conhecimentos de baixo para cima. Os poderosos impactos gerados nas duas estações de rádio comunitárias apresentadas aqui são muito semelhantes aos resultados de outros estudos comparáveis, todos tendo prestado atenção ao tema da causalidade, e os dois casos citados têm sido acompanhados anualmente por um período de cinco anos, reconfirmando o impacto.

A resposta para o que há dentro da pedagogia freiriana e de minhas próprias metodologias libertadoras de radiodifusão que causa a mudança, o que faz com que as comunidades sigam os conselhos de desenvolvimento veiculados por suas estações locais, é, na verdade, bastante simples. É porque a emissora é nossa; vemos e sentimos isso pelo fato de as emissoras comunitárias serem daqui, conhecidas e respeitadas, falando nossa língua - à nossa maneira e utilizando nossa cultura, nossas narrativas e nossa história, nossas expressões e saberes. Isso gera a confiança necessária para que mudanças poderosas aconteçam, porque inclui todos os princípios freirianos de amor, empatia, esperança $\mathrm{e}$ humildade. Juntos podemos fazer isso!

\section{DEPOIMENTO SOBRE PAULO FREIRE: "CONFIE NAS PESSOAS"}

CEES J. HA MELINK ${ }^{h}$

University of Amsterdam, Departament of Communication. Amsterdã, Países Baixos

Conheci Paulo Freire no início da década de 1970, quando ele trabalhou com o Conselho Mundial de Igrejas, e tive o privilégio de dividir um escritório com ele, enquanto trabalhava em projetos de comunicação alternativa para a Lutheran World Federation. Lembro que, no final de um longo dia de trabalho, Paulo muitas vezes olhava para mim e dizia: "Cees, nunca se esqueça, confie nas pessoas!". Desde então, essa frase continuou ressoando em minha
${ }^{\text {h}}$ Professor emérito de Comunicação Internacional na University of Amsterdam. E-mail: hamelink@antenna.nl 
mente, pois se tornou a base para o meu próprio trabalho em comunicação dialógica. Aprendi com Paulo que a base da liberdade comunicativa que deve orientar a comunicação humana é a confiança. Também aprendi que a confiança significa que preciso saber que o que o outro diz é genuíno, e o outro deve ter certeza de que o que eu digo é autêntico. Encontramos uma inspiração compartilhada em Martin Buber, que acreditava que só posso falar com alguém, no verdadeiro sentido do termo, se esperar que essa pessoa aceite minha palavra como genuína. A confiança é essencial para vivermos juntos. É a base do comportamento cooperativo social. Cooperamos porque contamos que os outros sejam de confiança. Se eles não forem confiáveis, não pode haver cooperação. A confiança é uma relação de dependência, baseada na expectativa de que essa dependência não será submetida a abuso, e essa expectativa pode estar ancorada no conhecimento sobre o comportamento anterior do outro, ou o conhecimento sobre seu caráter, ou fortes sentimentos afetivos. Se um encontro começa com a desconfiança, ou seja, a crença de que não se pode confiar no outro para falar a verdade, cumprir o que promete ou um compromisso, uma conversa pode ser possível, mas não um diálogo real. Na comunicação dialógica, é necessário confiar nos parceiros de conversação. Igualmente importante, no entanto, é que você precisa ser confiável como parceiro. Assim, a comunicação dialógica também é um exercício de autorreflexão crítica. Posso ter certeza de que sou confiável? Eu confio em mim mesmo? Acredito na minha própria verdade?

Entendo o significado da confiança na compreensão de que a outra pessoa seja livre em sua comunicação. Lembro-me de uma noite no saguão John Knox, em Genebra, quando o público esperava receber a grande sabedoria do guru Freire. No entanto, Paulo se recusou a desempenhar esse papel. Ele sentou-se à frente da plateia e disse: "Por favor, compartilhem seus conhecimentos comigo". Depois de um momento de paralisia, as pessoas começaram a falar e discutir. Naquela noite, vi meu amigo praticando a liberdade comunicativa. O respeito pela liberdade comunicativa dos outros é um reconhecimento básico de sua agência humana e exige que aceitemos o outro como fundamentalmente diferente de nós, e vejamos sua alteridade como uma característica única que não pode ser assimilada e reduzida à similaridade. A comunicação dialógica abre a possibilidade de reconhecer que uma posição diferente é justificada e que pode haver diferenças reais e Alteridade genuína. No diálogo, os participantes não se apegam a apenas uma posição como a verdade absoluta. Eles aceitam a disposição de lidar com diferenças reais e profundas. O respeito pela liberdade comunicativa do outro é um reconhecimento da dignidade da agência humana. Se negarmos 
às pessoas a agência, não as aceitamos como seres autônomos, como seres definidos por si mesmos e encarregados de suas próprias vidas. Descobri nessa noite que a comunicação dialógica é uma condição fundamental para a verdadeira humanização. Também que o diálogo não pode existir sem um profundo amor pelo mundo. Em sua correspondência com Karl Japsers, Hannah Arendt escreveu que queria que seu livro sobre teorias políticas (que ela nunca finalizou) tivesse o título Amor Mundi. Paulo entendeu que relações significativas não opressivas com os outros só são possíveis com base no amor pelo mundo.

No escritório de Genebra, com frequência falávamos sobre o poder. Como estudante do poder da propaganda, me referia ao poder como foi classicamente definido por Robert Dahl (1957), "A tem poder sobre B na medida em que ele pode fazer com que $B$ faça algo que $B$ não faria de outra forma" (p. 202). Paulo me ajudou a ver a outra dimensão do poder. O poder não só no sentido adversarial, competitivo, mas também no espírito de mutualidade e solidariedade (Freire, 1970b, p. 69). O poder como um processo recíproco de empoderamento. O poder de fazer algo, que também foi visto por Hannah Arendt (1970) como "a capacidade humana não apenas de agir, mas de agir em comum acordo" (p. 44). Através de nossas discussões pude ver o poder como capacidade, como potencialidade e como um recurso que continua a ser altamente distribuído de maneira desigual no mundo.

Quando ingressei mais tarde no mundo acadêmico, o espírito de Paulo estava lá novamente. Descobri que a maioria das políticas e práticas educacionais concebiam a educação como um instrumento para facilitar a conformidade dos alunos com o sistema político-econômico e sociocultural vigente. Paulo lembrou que a educação deve ser um meio pelo qual homens e mulheres lidam criticamente com a realidade e descobrem como participar da transformação de seu mundo. A educação, como Paulo diria, nunca é um processo neutro. Temos que escolher entre dois modos de pensamento opostos. A abordagem da conformidade (que parece ser cada vez mais dominante em todo o mundo) versus a abordagem da liberdade (inspirada na obra de Paulo). Em todo o mundo, ao falar com professores, estudantes e políticos responsáveis pelas políticas educacionais, vi um predomínio da mentalidade de conformidade, o que confirmou a visão de Bertrand Russell (1916) de que

A prevenção do livre questionamento é inevitável quando o propósito da educação é produzir crença em vez de pensamento, obrigar os jovens a ter opiniões positivas sobre temas duvidosos, em vez de deixá-los ver a dúvida e serem encorajados à independência mental. (p. 107) 
Ao contrário disso, a abordagem da conformidade continua a manifestar-se das seguintes formas:

A educação está rapidamente se tornando uma arena de vencedores e perdedores: um modelo de competição prevalece com foco no resultado econômico, de modo que a quantidade ganha a disputa contra a qualidade. Isso implica que programas financeiramente menos bem-sucedidos serão cassados. É crucial obter a maior pontuação possível no índice Hirsch: um padrão de medição com pouca validade que combina citações com produtividade, mas não diz nada sobre a qualidade da pesquisa. As instituições acadêmicas tornam-se entidades egoístas lutando pela maior parte do bolo. A maior participação (ou qualquer participação) nos decrescentes fundos para pesquisa significa que as equipes de pesquisa educacional precisam gastar quantidades de tempo desproporcionais para preparar, na maioria dos casos, propostas de projetos de investigação malsucedidas.

A educação acadêmica no espírito de Paulo estimularia o que Russell chamou de "o amor da aventura mental", enquanto na abordagem da conformidade não há espaço para o tipo de diálogo que Paulo via como central para a transformação do mundo. A escolha entre as abordagens da conformidade e a da liberdade pode ser colocada como escolha entre o presidente Jair Bolsonaro e o filósofo Paulo Freire. Ou, como a neta de Freire escreve, entre eliminar o legado de seu avô ou celebrar sua abordagem libertadora da educação.

Os temas favoritos nas discussões no restaurante do Edifício Ecumênico na Rota de Ferney trataram da questão do discurso racional versus a imaginação. Enquanto Paulo enfatizava a importância da racionalidade, da consciência e do uso da linguagem, eu queria que a comunicação dialógica fosse reencantada e libertada do discurso racional. Tendo lido - muitos anos depois - a crítica de Enrique Dussell à ética discursiva proposta por KarlOtto Apel e Jurgen Habermas (Dussell \& Ape, 2013), acho que Paulo teria concordado com Dussell que o diálogo genuíno como ação política não deveria ser baseado em argumentação racional, mas incorporar a realidade da exploração e da exclusão.

Se nossas pausas no café em Genebra tivessem durado mais, gostaria de perguntar se ele tinha lido Por Quem os Sinos Dobram de Hemingway (1940). Ele provavelmente leu, mas leu com o mesmo fascínio que Merleau Ponty e Sartre tinham por esse livro?

Como sempre no encontro com grandes mentes, muitas perguntas ficam sem resposta. No entanto, mesmo que fossem críticas, tenho certeza de que Paulo as teria levado a sério, respondendo com uma genuína mente aberta. 


\section{HOMENAGEM A PAULO FREIRE EM SEU CENTENÁRIO'}

FRE B B T T O

Pesquisador independente. São Paulo, SP - Brasil

Quando Paulo Freire retornou de 15 anos de exílio, em agosto de 1979, nos encontramos em São Paulo. Éramos vizinhos e, com frequência, nos visitávamos. Estreitamos muito as nossas relações pessoais e isso nos permitiu inclusive escrever um livro, que foi mediado pelo jornalista Ricardo Kotscho, chamado Essa Escola Chamada Vida (2000).

Paulo ficou doente em 1997 e veio a falecer no dia 2 de maio daquele ano. Eu estive junto a ele nos momentos finais, nos momentos que eu chamo de transvivenciação, e, logo em seguida, eu escrevi um texto, que eu acho que traduz bem toda a metodologia do professor Paulo Freire:

"Ivo viu a uva", ensinavam os manuais de alfabetização. Mas o professor Paulo Freire, com o seu método de alfabetizar conscientizando, fez adultos e crianças, no Brasil e na Guiné-Bissau, na Índia, na Nicarágua e em tantos outros lugares, descobrirem que Ivo não viu apenas com os olhos. Viu também com a mente e se perguntou se uva é natureza ou cultura.

Ivo viu que a fruta não resulta do trabalho humano. É Criação, é natureza. Paulo Freire ensinou a Ivo que semear uva é ação humana na e sobre a natureza. E a mão, multiferramenta, desperta as potencialidades do fruto. Assim como o próprio ser humano foi semeado pela natureza em anos e anos de evolução do Universo.

Colher a uva, esmagá-la e transformá-la em vinho é cultura, assinalou Paulo Freire. O trabalho humaniza a natureza e, ao realizá-lo, o homem e a mulher se humanizam. Trabalho que instaura o nó de relações, a vida social. Graças ao professor, que iniciou sua pedagogia revolucionária com trabalhadores do Sesi de Pernambuco, Ivo viu também que a uva é colhida por boias-frias, que ganham pouco, e comercializada por atravessadores, que ganham muito mais.

Ivo aprendeu com Paulo que, mesmo sem ainda saber ler, ele não é uma pessoa ignorante. Antes de aprender as letras, Ivo sabia erguer uma casa, tijolo a tijolo. O médico, o advogado ou o dentista, com todo o seu estudo, não são capazes de construir como Ivo. Paulo Freire ensinou a Ivo que não existe ninguém mais culto do que o outro, existem culturas paralelas, distintas, que se complementam na vida social.

Ivo viu a uva e Paulo Freire mostrou-lhe os cachos, a parreira, a plantação inteira. Ensinou a Ivo que a leitura de um texto é tanto melhor compreendida quanto mais se insere o texto no contexto do autor e do leitor. É dessa relação dialógica entre texto e contexto que Ivo extrai o pretexto para agir. No início e no
${ }^{i}$ Este depoimento foi extraído da palestra realizada por Frei Betto no ciclo de debates Paulo Freire Centennial: 7 Talks in Preparation for the Next 100 Years, realizado pela Loughborough University London, em março de 2021.

Ver: Libanio Christo (2021).

Escritor, autor de Por Uma Educação Crítica e Participativa (Rocco) e de Essa Escola Chamada Vida (Ática), em parceria com Paulo Freire e Ricardo Kotscho. 
${ }^{\mathrm{k}}$ Professora Titular de Teoria Literária e Literatura Comparada da Universidade de São Paulo (USP) aposentada e primeira catedrática de Literatura e Cultura Brasileira na Alemanha junto à Freie Universität Berlin. E-mail: lchiappini@gmail.com ${ }^{5}$ Educadora e advogada, profundamente engajada na democratização do ensino público de qualidade, ela muito estudou e reinventou Paulo Freire em sala de aula, tendo tido também um contato pessoal com ele num congresso de que participou na Bahia, ainda nos anos 1960. Seu entusiasmo pela figura humana e pelo pensamento pedagógicofilosófico-político desse grande educador, me contagiou por meio de muitas conversas e leituras exemplares.

${ }^{6}$ Das insatisfações com esse trabalho, concebido pela Universidade como reciclagem, nasceu minha vontade de, associando-me a outros e outras colegas igualmente insatisfeitos/as criar alternativas mais na linha freiriana.

Daí nasceu, no final de 1970, a Associação de Professores de Língua e Literatura, da qual fui sócia fundadora e primeira vicepresidente e, mais tarde, já nos anos de 1990, um projeto que até hoje é a menina dos meus olhos, de formação do educador em serviço (EFES), que rendeu, entre outras coisas, 14 livros da coleção Aprender e Ensinar com Textos (Chiappini, 2015). fim do aprendizado, é a práxis de Ivo que importa. Práxis-teoria-práxis, num processo indutivo que torna o educando sujeito histórico.

Ivo viu a uva e não viu a ave que, de cima, enxerga a parreira e não vê a uva. O que Ivo vêé diferente do que vê a ave. Assim, Paulo Freire ensinou a Ivo um princípio fundamental de epistemologia: a cabeça pensa onde os pés pisam. O mundo desigual pode ser lido pela ótica do opressor ou pela ótica do oprimido. Resulta uma leitura tão diferente uma da outra como entre a visão de Ptolomeu, ao observar o sistema solar com os pés na Terra, e a de Copérnico, ao imaginar-se com os pés no Sol.

Agora Ivo vê a uva, a parreira e todas as relações sociais que fazem do fruto festa no cálice de vinho, mas já não vê Paulo Freire, que mergulhou no Amor de Deus na manhã de 2 de maio de 1997. Deixa-nos uma obra inestimável e um testemunho admirável de competência e coerência.

Paulo deveria estar em Cuba, onde receberia o título de Doutor Honoris Causa, da Universidade de Havana. Contudo, antes de embarcar fui rezar com Nita, sua mulher, e os filhos, em torno de seu semblante tranquilo: Paulo via Deus.

\section{VIAGEM À "INTIMIDADE DO ÓBVIO”}

\author{
LIGIA CHIA P PINI ${ }^{k}$ \\ Universidade de São Paulo, Faculdade de Filosofia, Letras e Ciências Humanas. São Paulo - SP, Brasil \\ Freie Universität Berlin, ZI Lateinamerika-Institut. Berlim, Alemanha
}

Para Leda Gusmão Chiappini

\section{Antecedentes e destaques de uma conversa inesquecível}

Este breve texto tem como centro a conversa no subtítulo referida, circunstanciada brevemente por algumas lembranças anteriores, pois muito antes dela, houve alguns encontros decisivos, mesmo que indiretos, com Paulo Freire, seja por referências à sua obra, seja por testemunho de quem já o havia visto e escutado pessoalmente. Como foi o caso, de minha irmã, Leda Gusmão Chiappini, a quem dedico estas lembranças ${ }^{5}$.

Daí para começar a ler e refletir sobre o grande educador e seu assim chamado método, foi quase um passo natural, à medida em que, terminando meus estudos de Letras e iniciando-me na docência, no chamado ensino médio e no universitário, fui cada vez mais tentando praticar uma pedagogia dialógica, o que incluiu também os cursos de extensão, ministrados para professores de primeiro e segundo graus 6 . 
Entre 1978 e 1979, fiz uma pesquisa de pós-doutorado na França ${ }^{7}$, sobre Literatura e Ensino, que, além dos seminários em diferentes Universidades, e de estágios, colóquios e muita leitura sobre educação em geral e ensino de literatura, em particular, motivou-me a realizar diversas entrevistas com estudantes e professores/as os/as mais variados/as. No caso de Paulo Freire, depois de um estudo sistemático da sua obra, publicada até então, aproveitei a relativa proximidade de Paris e Genebra, para entrevistá-lo também.

Nesta homenagem ao seu jubileu, tendo sido convidada a narrar um pouco do meu convívio com ele, optei por relembrar brevemente aquele nosso encontro, em Genebra, quando tivemos uma conversa simpática, fecunda e, por isso mesmo, inesquecível ${ }^{8}$. Sim, porque não se tratou apenas de uma entrevista, em que a entrevistadora pergunta e o entrevistado responde. Foi uma verdadeira conversa, no sentido etimológico da palavra, aparentada ao verbo conviver e também a direcionar e redirecionar pensamento e fala no contato com outra(s) pessoa(s). Mais do que falar e ouvir, tratava-se de dialogar, conceito chave no pensamento e na prática de Paulo Freire.

As perguntas que lhe encaminhara por carta, com a devida antecedência, hoje percebo, eram "sobre Deus e o mundo". Mas Paulo soube escolher aquelas que poderiam ser norteadoras de uma reflexão a partir de algumas práticas fundantes da sua pedagogia ${ }^{10}$. Assim, deu o tom da conversa, relembrando o início de seu trabalho pedagógico, no Serviço Social da Indústria (SESI), com os pais e professores das suas escolas. Tratava-se dos "círculos de pais e professores", considerados posteriormente, por ele mesmo, como "um capítulo da educação de adultos". Dessa experiência destacou um episódio marcante para o desenvolvimento teórico e prático do seu trabalho pedagógico, narrando de modo muito comovente e comovido suas primeiras tentativas de interferir junto às famílias dos alunos, para acabar com os frequentes castigos físicos que estes sofriam dos pais. Sua tentativa de ensinar que isso não devia ser feito teria provocado uma verdadeira aula por parte de um desses pais, que the ensinou a aprender com o educando. A partir, sobretudo, da percepção direta dos problemas sociais que estes enfrentavam, sendo trabalhadores sempre cansados, morando, dormindo e comendo mal, em contraste com as condições sociais que ele parecia adivinhar no mestre, descrevendo com muita concretude a casa de Paulo e sua família, confortável, com um quarto para cada criança e muita comida na mesa (Leite, 2005, pp. 309-310).

Episódios como esse se transformaram, para o, desde então, educador-educando, em referencias paradigmáticas para guiar o trabalho do pensamento pelos labirintos do conhecer. E daí resultou, entre outras, esta reflexão acerca do aparentemente óbvio:
${ }^{7}$ Com bolsa de pós-doutorado, concedida pela FAPESP.

${ }^{8}$ Foi uma conversa a três, pois dela também participou um colega dos Seminários que frequentávamos na École de Hautes Études de Paris. Trata-se do filósofo chileno Antonio Faúndez, também exilado na época. Sua participação foi aceita por Paulo, a quem o apresentei na carta em que solicitava a confirmação da entrevista. Dando um exemplo de abertura e disponibilidade ao diálogo, Paulo não apenas o recebeu, como ouviu com paciência e respeito suas críticas, de marxista ortodoxo, vendo nelas uma oportunidade a aproveitar para esclarecer melhor suas ideias, para o outro e para si mesmo, aprendendo democraticamente com o contraditório, atitude rara até hoje, quando as polarizações tendem a apresentar-se de modo raivoso e insuperável. Esse intercâmbio foi tão importante que acabou deslanchando uma parceria duradoura entre ambos, inclusive na publicação de livros dialógicos, livros que conversam, como é o caso de Por uma Pedagogia da Pergunta (Freire, 2012).

${ }^{9}$ Retomando a expressão do mestre Antonio Candido, sobre algumas formulações iniciais dos projetos de tese que orientava.

${ }^{10} \mathrm{~A}$ entrevista completa, com todas as perguntas enviadas e um comentário atualizado inicial, foi republicada em Leite (2005). 
${ }^{11}$ Esse texto, com pequenas diferenças circula em outras publicações de antes e depois dos cadernos editados para uso em São Tomé e Príncipe.
${ }^{12}$ Vale lembrar, porém, que ele dedicou um de seus primeiros livros ao tema, mas centrandose, poderíamos dizer, na falta de comunicação real da maior parte do trabalho desenvolvido por expertos nos programas de extensão, especialmente no contexto rural, em que ele atuou, no Departamento de Extensão Cultural da Universidade do Recife, onde a prática do ensino da língua, vinculada ao processo de comunicação, o teria levado a refletir sobre a educação como extensão. Por isso torna-se difícil pensar a extensão em

Paulo Freire sem o ato de comunicar-se, para além do mero "comunicado".
Estou convencido hoje de que se tem que quebrar o óbvio e expor a intimidade do óbvio. E quando você faz isso, descobre que o óbvio não é tão óbvio quanto se pensa. É óbvio para você num certo momento, mas não é para muita gente. (Leite, 2005, p. 311)

\section{Um texto óbvio?}

Entre tantas outras coisas, na longa conversa, vale a pena destacar também o que Paulo falou sobre sua atuação no processo de pós-alfabetização em São Tomé e Príncipe, realizado já em pleno exílio genebrino. Para melhor ilustrar o material elaborado aí, sob sua coordenação, e seus objetivos político-pedagógicos, leu em voz alta um texto, aparentemente simples, que tem muito a ver com o conceito freiriano de diálogo e da comunicação dialógica, no processo do estudo e da aprendizagem, vinculados à experiência de vida e trabalho dos educandos. Eis o texto ${ }^{11}$ :

Tinha chovido muito toda noite. Havia enormes poças de água nas partes mais baixas do terreno. Em certos lugares, a terra, de tão molhada, tinha virado lama. Às vezes, os pés apenas escorregavam nela, às vezes mais do que escorregar os pés se atolavam na lama até acima dos tornozelos. Era difícil andar. Pedro e Antonio estavam a transportar, numa camioneta, cestos cheios de cacau, para o sítio onde deveriam secar. Em certa altura perceberam que a camioneta não atravessaria o atoleiro que tinham pela frente. Pararam, desceram da camioneta, olharam o atoleiro, que era um problema para eles. Atravessaram a pé uns dois metros de lama, defendidos pelas suas botas de cano longo. Sentiram a espessura do lamaçal. Pensaram. Discutiram como resolver o problema. Depois, com a ajuda de algumas pedras e de galhos secos de árvores, deram ao terreno a consistência mínima para que as rodas da camioneta passassem sem se atolar. Pedro e Antônio estudaram. Procuraram compreender o problema que tinham de resolver e, em seguida, encontraram uma resposta precisa. Não se estuda apenas na escola. Pedro e Antônio estudaram enquanto trabalhavam. Estudar é assumir uma atitude séria e curiosa diante de um problema. (Leite, 2005, p. 321)

Paulo escreveu pouco e falou pouco sobre comunicação ${ }^{12}$, mas a dramatizou incansavelmente no diálogo com seus educandos de diversas proveniências e idades. E, nesta nossa conversa, disse explicitamente que considerava a comunicação a base da educação, revelando assim, como no caso da base marxista e cristã do seu pensamento e da sua prática, parte do que, nos seus escritos, se expressa frequentemente em silêncios plenos de significado. Explicou, 
ainda, que ensinar e estudar a língua portuguesa e fazer leituras no campo da filosofia e da psicologia da linguagem lhe teriam tornado evidentes as relações estreitas entre educação e teoria do conhecimento. Conhecer e educar, possibilitando aos educandos exercer o trabalho do pensamento, implicaria pensar a prática ${ }^{13}$, sempre social. E dialogar, em conversas que ganhariam uma dimensão de trabalho, ao examinar, analisar e propor. Exatamente o que ocorre no pequeno texto, em que Antônio e Pedro param, descem juntos do carro para examinar o terreno, olham, pensam, discutem, identificam o problema e encontram, conjuntamente, a solução para sair do atoleiro. O texto ganha, assim, emblematicamente, uma dimensão alegórica, apontando saídas da confusão que impede o avanço para a luz do conhecimento e impõe o ato propositivo para, só assim, superar uma situação problemática ${ }^{14}$.

Estudar, comunicar, discutir, conversar, tudo isso está na obra teórica e prática de Paulo Freire e se mostrou em vários aspectos desta nossa conversa, inclusive nesse pequeno-grande-simples e complexo exemplo do trabalho de pós-alfabetização em São Tomé e Príncipe.

\section{Depois eu conto: voltar para reaprender, reensinar e reinventar o Brasil}

Ao voltar do exílio, logo no início dos anos 1980, Paulo declarou aos jornalistas de primeira hora, que lhe perguntavam o que iria fazer: antes de mais nada reaprender o Brasil.

Nesse primeiro tempo da volta, tivemos o privilégio de sermos recebidos em sua casa, por ele e D. Elsa, sua esposa e, no começo de tudo, mestra. Aí retomamos, em meio a uma deliciosa feijoada pernambucana, nossa conversa sobre sua obra, que nesse momento, segundo ele, vinha sendo criticada. Mas só do ponto de vista teórico, sem a devida atenção ao seu permanente esforço em relacionar teoria e prática. Isso, porém, não foi o ponto central da retomada do nosso contato. Este se deu quando ele se tornou secretário de educação do governo de Luísa Erundina (entre 1989 e 1991), e fez um convite amplo a professores das universidades paulistas, sobretudo Universidade de São Paulo, Pontifícia Universidade Católica e Universidade de Campinas, para atuarem como assessores na reorientação curricular das escolas paulistanas de nível elementar e médio, bem como na formação de educadores e educadoras. Nesse projeto, que contou no seu início com perto de cem assessores dessas três universidades, tive a honra de colaborar do início ao fim, quando restaram apenas dez deles. Mas isso é outra história a ser recontada com mais tempo e espaço, talvez em parceria com outros/as participantes, que aí perseveraram. Fica em aberta a possibilidade de, posteriormente, nesta ou em outra revista
${ }^{13}$ Nesse sentido, seus livros não seriam propriamente livros, mas "livros-relatórios".
${ }^{14} \mathrm{~A}$ Educação como produtora de conhecimento, revela-se, por isso mesmo, um ato político, na medida em que quem se educa pensando e para pensar dialogando, aprendendo e ensinando, resiste a imposições de pensamentos prontos, alheios e alienantes. Aí se sublinha não apenas a concepção da não neutralidade do ensino, como o seu caráter dialógico, concebido na formação da cidadania, como ato educomunicativo, o que vem explicado exemplarmente no texto de Citelli et al. (2019). 


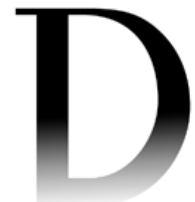

${ }^{15}$ Onde também se mostrou notório o papel da chamada pedagogia da correspondência.

As cartas foram utilizadas e, mais tarde, publicadas em livro, como estratégia de comunicação e formação de professor@s, mais especialmente, das professoras, que procurou livrar da condição de tias para reapresentá-las às/ aos leitoras/es e a elas mesmas, enquanto educadoras. Ver: Pereira Coelho (2011).

${ }^{1}$ Professora Associada aposentada e ex-diretora do College of Development Communication, University of the Philippines Los Baños. Orcid: https://orcid.org/00000001-9068-7675. E-mail: mchcadiz@gmail.com

${ }^{\mathrm{m}}$ Professor Assistente da University of the Philippines Los Baños. Orcid: https://orcid. org/0000-0002-5534-6709.

E-mail: lbcarpio@up.edu.ph

${ }^{\mathrm{n}}$ Professor Associado do Department of Development Journalism, College of Development Communication, University of the Philippines Los Baños. Orcid: https://orcid. org/0000-0002-3142-6878.

E-mail:pacustodio1@up.edu.ph

${ }^{\circ}$ Professor Assistente, Department of Science Communication, College of Development Communication, University of the Philippines Los Baños. Orcid: https://orcid. org/0000-0002-5780-1787.

E-mail:wbdagli@devcom.edu.ph

P Professor Associado, Department of Educational Communication, College of Development Communication, University of the Philippines Los Banos. Orcid: https://orcid.org/00000003-2264-6526. E-mail: momoscoso@devcom.edu.ph

${ }^{\mathrm{q}}$ Professor Associado e diretor titular, College of Development

Communication, University of the Philippines Los Baños.

Orcid: https://orcid.org/00000003-2264-6526. E-mail: msctirol@devcom.edu.ph especializada, pensarmos em algo mais amplo, incluindo essa experiência pioneira da prefeitura de São Paulo ${ }^{15}$.

\section{ESTABELECENDO A IDENTIDADE CENTRAL DA COMUNICAÇÃO PARA O DESENVOLVIMENTO EM PAULO FREIRE: UM TESTEMUNHO DA UNIVERSITY OF THE PHILIPPINES - COLLEGE OF DEVELOPMENT COMMUNICATION (UPLB CDC)}

\author{
MARIA CELESTE CA DIZ1 \\ LYNETTE CARPIO-SERRA NO m \\ PAMELA MARIA A. CUSTODIO \\ WINTFRDO DA G L I ${ }^{\circ}$ \\ MILDRED MOSCOSOP \\ MA. STELLA C. TTROLq \\ University of the Philippines Los Baños, College of Development Communication. Los Baños - \\ Laguna, Filipinas
}

Para nós, a alma e a essência da comunicação para o desenvolvimento como disciplina acadêmica, profissão e prática, encontra base na filosofia e na abordagem de Paulo Freire da humanização dos oprimidos pelo despertar de sua consciência crítica, por meio do diálogo, dentro de sua matriz de amor, humildade, fé nas capacidades, esperança e pensamento crítico dos pobres.

Gerações de praticantes e profissionais, professores e pesquisadores da comunicação para o desenvolvimento (Devcom), principalmente nas Filipinas, mas também espalhados pelo sudeste da Ásia e outras regiões do sul, como a África e o sul da Ásia, que são estudantes da University of the Philippines Los Baños - College of Development Communication (UPLB - CDC) ou UPLB - Devcom, adotaram os princípios fundamentais da filosofia e os ensinamentos de Freire como base da comunicação para o desenvolvimento participativo, que capacita os pobres e marginalizados como sujeitos de seu desenvolvimento, para a realização do seu potencial completo como humanos com dignidade. Esses ex-alunos de Comdev também estão orientando futuros profissionais, professores e pesquisadores da disciplina em 22 outras instituições acadêmicas nas Filipinas, além de algumas em outros países em desenvolvimento.

A UPLB Devcom emergiu como pioneira na oferta do bacharelado, mestrado e doutorado de filosofia em Devcom nos anos 1970, semeada pelo artigo seminal da Dra. Nora Cruz Quebral (1971), definindo o conceito e o 
embrião da disciplina em uma conferência sobre desenvolvimento agrícola em 1971, em Los Baños ${ }^{16}$.

O foco da definição da Devcom de Quebral (1971) nos pobres e marginalizados, que os ex-alunos da UPLB Devcom consideraram fundamental, alinha-se ao de Freire em relação aos oprimidos e seu empoderamento como seres humanos com dignidade:

a arte e a ciência da comunicação humana aplicadas à rápida transformação de um país e da massa de seu povo da pobreza a um estado dinâmico de crescimento econômico, que possibilita maior igualdade social e maior realização do potencial humano. (p. 1)

A definição foi revisada, em 2012, como "a ciência da comunicação humana vinculada à transição das comunidades da pobreza, em todas as suas formas, a um crescimento global dinâmico, que promova a equidade e o desenvolvimento do potencial individual" (Quebral, 2012, p. 9).

Enquanto membros da terceira e quarta geração da UPLB Devcom (Quebral, Juan F. Jamias, Ely D. Gomez, entre os da primeira geração, e Felix Librero, Teresa H. Stuart e Madeline Mag-uyon-Suva, entre os da segunda), ouvimos pela primeira vez Paulo Freire ser brevemente mencionado por nossos mentores em algumas aulas de graduação, e estudaríamos sua Pedagogia do Oprimido em profundidade na pós-graduação, se tivéssemos sorte. Para aqueles de nós que tiveram $o$ privilégio de interrogar seu trabalho, descobrimos agradavelmente a própria essência da Devcom nas publicações de Freire, cujo discurso animou nossos corações ${ }^{17}$.

Nossos professores de primeira geração, Quebral, Jamias e Gomez, em seus respectivos escritos dos anos 1970, afirmaram que a Devcom é plena de valores, e a Dra. Quebral nos disse isso várias vezes em nossas muitas privilegiadas interações formais e informais. Encontramos essa dimensão articulada nas obras de Freire. Enquanto a Devcom influenciada por Freire é frequentemente rotulada como participativa, a Dra. Quebral sempre afirmou que a etiqueta é redundante, ressaltando que a Devcom é intrinsecamente participativa.

Em nossos currículos, examinamos, entre outros conceitos e teorias, o diálogo de Freire em cursos fundamentais nos programas de graduação e pós-graduação. Eles compõem especificamente a base do curso de graduação DEVC 70 Comunicação Interpessoal em Desenvolvimento (Interpersonal Communication in Development), criado em 1992, no terceiro ano da graduação. O curso é mais prático e reflexivo do que teórico - convida os alunos a examinarem a si e a seus valores; enfatiza a vigilância e a perspectiva em vez da técnica; os municia com algumas regras básicas no trabalho comunitário; os expõe a situações reais na comunidade; os desafia a facilitar o diálogo problematizador e a autorreflexão para enfrentar desafios reais
${ }^{16}$ As raízes da UPLB Devcom remontam a um Escritório de Publicação e Extensão criado pela então University of the Philippines College of Agriculture (UPCA) em 1954. Foi elevada como um departamento acadêmico, Department of Agricultural Information and Communication, em 1962; renomeado Department of Agricultural Communication em 1968; e outra vez renomeado como Department of Development Communication em 1973. Começou a oferecer o mestrado em 1973; o bacharelado em Comunicação de Desenvolvimento (BSDC) em 1974; e o doutorado em 1976. Foi elevado como um Institute of Development Communication em 1987 e como uma faculdade plena em 1998. Até o momento, formou 3.019 no bacharelado, 309 no mestrado (Devcom) e 95 no doutorado (Devcom).

${ }^{17}$ Desde a década de 1960 , muitos membros do corpo docente da UPLB Devcom observaram uma profunda mudança nas noções institucionais de comunicação e desenvolvimento. A maioria deles concordou que há uma consciência e atitude crítica em relação à difusão comunicativa da inovação e mudança comportamental. Membros do corpo docente sênior, em particular, acreditavam que muitos deles vinham fazendo um trabalho muito semelhante à comunicação participativa antes mesmo de lerem autores latino-americanos críticos (Dagli, 2018). 
em uma comunidade, com a ajuda de simulações e exercícios; e espera que eles possam deliberadamente facilitar ou experimentar (dado os limites práticos de tempo) a práxis ou o processo de reflexão-ação, que, de outra forma, recai sobre os ombros de seus professores, para dar o salto inicial durante o curso, no mínimo. Isso fornece o equilíbrio que a Dra. Quebral há muito recomendava ao currículo necessário, além das habilidades de mídia oferecidas, aos graduandos.

DEVC 126, Jornalismo Participativo de Desenvolvimento (Participatory Development Journalism) (PDJ), iniciado em 2014, é um curso de jornalismo que visa aplicar a práxis de Freire como aprendizado em ação. Amplia os conceitos de jornalismo comunitário para incorporar, no ensino, o diálogo dos alunos e comunidades sobre a importância e a relação entre comunicação e mudança social nas bases. O curso valoriza a agência comunitária, ou seja, uma perspectiva de desenvolvimento que enfatiza o poder das comunidades de melhorar sua própria situação, ao narrar suas próprias histórias, nesse caso, com o uso da comunicação baseada na mídia e imbuída dos princípios do jornalismo, ou seja, a verificação para a narrativa veraz. As matérias produzidas pelas turmas de DEVC 126 passam pelo processo de narrar conjuntamente - um diálogo entre iguais -, no qual cada um aprende com o outro. Aqui, enfatizamos que a produção é tão boa quanto o processo narrativo, que engaja os participantes na reflexão e na autorreflexão em direção à conscientização e, eventualmente, vislumbrando caminhos para a emancipação. Nossos alunos aprendem com as comunidades sobre os pontos fortes e as oportunidades de base, uma visão fundamentada das aspirações do povo comum, sobre estar em uma posição privilegiada e como esse privilégio pode ser útil no trabalho para a mudança social.

Embora enfatize o papel das mídias digitais, o núcleo do jornalismo de desenvolvimento participativo se encontra no engajamento comunitário, que privilegia as vozes locais. Assim, realizar jornalismo de desenvolvimento participativo requer humildade e certa mentalidade de respeito ao conhecimento local, múltiplas perspectivas e o aprendizado compartilhado sobre a preocupação específica com o desenvolvimento da comunidade.

Uma característica fundamental da PDJ é a imersão na comunidade. Isso permite que nossos alunos experimentem a vida comunitária e conversem com os locais na esperança de incutir compreensão e empatia, que possam fazer com que as matérias que escrevem realmente contenham as vozes deles. Essa atividade também testa as habilidades na comunicação interpessoal, que aprenderam em DEVC 70, e aumenta sua consciência de que o conhecimento reside em todos que podem articular experiências e aspirações.

Em 2014, a UPLB Devcom institucionalizou um modelo de engajamento aluno-comunidade na maioria de seus cursos de nível superior, no programa 
de graduação, por meio de um programa educativo acadêmico em campo. Nesse modelo, os estudantes de graduação e as comunidades trabalham juntos ao planejar, desenvolver e manter iniciativas em Devcom que abordam questões comunitárias. Um comitê facilita as atividades, que apoiam a continuidade de planos guiados pela comunidade de um ano letivo para o outro, garantindo que os resultados acadêmicos dos estudantes de vários cursos contribuam para visões de longo prazo das comunidades parceiras. De várias formas, o programa de ensino de campo acadêmico da UPLB Devcom pode ser visto como um experimento pedagógico, no qual os alunos e comunidades parceiras aprendem a descobrir como é a conscientização na prática: que aprender a perceber e identificar as causas básicas dos elementos opressivos na sociedade só pode ocorrer em espaços e relações de convivialidade, e por meio de práticas institucionais que fomentam o diálogo e a ação emancipatórios (Freire, 1970c).

Uma disciplina de doutorado, DEVC 391, Comunicação para o Desenvolvimento Participativo (Participatory Development Communication), possui uma ementa que diz:

O desenvolvimento no século XXI é marcado por comunidades em transição e sensibilidades para diferentes culturas e contextos, e destaca a inclusão na tomada de decisões e planejamento das direções para a mudança. As abordagens participativas adotam uma pluralidade de perspectivas e diversidade cultural adequadas às demandas do momento.

A disciplina discute abordagens participativas em comunicação para o desenvolvimento e pesquisas derivadas da práxis de Freire em comunicação comunitária, educação de adultos, pesquisa-ação participativa e planejamento, monitoramento e avaliação participativos. As discussões também incluem os modelos e as abordagens adaptados localmente, como ADIDS ou ação, discussão, entrada, aprofundamento e síntese (Networks, 2001 citado em Daya, 2010) processo de aprendizagem, e Inquérito Socialmente Compartilhado (Alfonso, 2000) para a pesquisa.

Junto com as transformações no pensamento sobre a comunicação e desenvolvimento e a crescente influência de Freire, houve uma mudança de foco e base teórica dos docentes e das pesquisas estudantis. A comunicação para o desenvolvimento, ao estilo Los Baños, possui raízes no modelo de extensão agrícola americana (modelos de adoção de tecnologia e modernização) informado por teorias sociopsicológicas e de informação sobre a comunicação. As pesquisas nas primeiras décadas da Faculdade foram fortemente influenciadas por esses enquadramentos teóricos, com algumas exceções.

Alexander G. Flor (2004) escreveu e publicou alguns trabalhos sobre suas próprias articulações da conscientização de Freire: conscienti-canção para músicas de 
protesto do movimento social nas Filipinas nos anos 1980-1990 e conscienti-atuação observando o papel dos teatros comunitários na mudança rural na mesma época.

Nos anos mais recentes, porém, a pesquisa ganhou horizontes mais amplos movendo-se para o território das tradições críticas e culturais que prestam atenção às vozes marginais e autênticas (por exemplo, Amoyan \& Custodio, 2019), e a poética e a política de participação e empoderamento (por exemplo, Baurile, 2014; Guanio, 2017; Timbreza, 2018).

Reconhecendo que as instituições de ensino carregam vestígios de ideologias conservadoras, autoritárias e coloniais, a influência dos valores freirianos na pesquisa e nas ofertas de cursos pode ser vista como uma preparação para descolonizar o currículo da Faculdade, e reimaginar uma identidade para nós mesmos, mais fundamentada em formas críticas de ver.

Em meio às fortes ondas de discursos concorrentes sobre desenvolvimento e comunicação, a pedagogia e os valores de Freire têm proporcionado uma âncora para a comunicação para o desenvolvimento olhar para si mesma e ver seu valor como campo e disciplina.

À medida que as instituições em todo o mundo encontram maneiras de enfrentar problemas socioecológicos de alta complexidade, a UPLB Devcom continuará a encontrar inspiração na pedagogia da libertação de Freire na transformação das causas básicas da desigualdade, vulnerabilidades e injustiças, por meio da comunicação reflexiva e dialógica. Ao contrário das décadas anteriores, quando o papel da Devcom era, em grande medida, de apoio ao estabelecimento do que agora se tornou o regime dominante de conhecimento e poder sobre o desenvolvimento global, e ao criticar os limites desse regime, a Devcom, nas próximas décadas, deve contribuir para a coprodução de novos regimes de conhecimento e poder, aqueles que apoiam sociedades e instituições em direção a futuros sustentáveis, mais justos e equitativos. Agora, mais do que nunca, o pensamento reflexivo e crítico é necessário para transformar pressuposições prévias sobre a ciência/conhecimento, o poder, a comunicação e a mudança.

\section{PAULO FREIRE E O SENTIDO DO ATO DE EDUCAR}

${ }^{\mathrm{r}}$ Professora Titular do Programa de Pós-Graduação em Letras da Universidade Presbiteriana Mackenzie (UPM), é doutora em Administração pela UPM e doutora em Educação pela USP. Orcid: https://orcid.org/00000002-8775-9436. E-mail: vasconcelos.pos@mackenzie.br

\author{
MARIA LUCIA M. CARVALHO VASCONCELOS \\ Universidade Presbiteriana Mackenzie, Programa de Pós-Graduação em Letras. São Paulo - SP, Brasil
}

Sou professora. Mais que isso, sou professora formadora de professores. Dito isto, explico-me ao afirmar que minha preocupação vai muito além de apresentar a meus/minhas alunos(as) métodos e técnicas de ensino. Preocupa-me 
o entendimento que eles(as) venham a ter do que virá a ser para cada um(a) o exercício profissional da função docente.

No período em que cursei minha Licenciatura em Pedagogia, na Universidade de São Paulo (USP), Paulo Freire estava excluído das universidades brasileiras por conta da ditadura militar iniciada em 1964 que, inclusive, levou-o a um longo período de exílio (de 1964 a 1979). Só depois de formada é que tive contato com sua obra e conhecê-la foi como dar sentido às ações diárias que eu vinha desempenhando como professora.

O contato com a filosofia e obra de Paulo Freire clareou para mim o sentido do ato de educar. A partir da ressignificação da prática do diálogo e da apropriação de diversos conceitos por ele apresentados, como consciência crítica, educação libertadora, inédito viável dentre outros, tais conceitos foram incorporados ao meu fazer pedagógico diário e uma nova acepção do ato de educar foi construída.

Se educação é conscientização, como eu, professora que sou, poderia despertar em meu alunado a desejável curiosidade crítica diante dos fatos e efeitos de sua realidade se não olhasse, eu mesma, criticamente, para o meu fazer profissional?

Para Freire (1983), o que caracteriza a consciência crítica, não preconceituosa, inquieta, dentre tantas outras peculiaridades, é a busca pelo conhecimento dos fatos, sabendo-se que a realidade é mutável e que o indivíduo, também mutável, é sujeito de sua própria história.

"Se os homens (e mulheres) são seres do quefazer é exatamente porque seu fazer é ação e reflexão" (Freire, 1968/2015, p. 121). Todo(a) professor(a) deve, por consequência, estimular em suas aulas, com o grupo discente, $o$ ato de agir e refletir sobre a ação. A autonomia de nossos(as) alunos(as), disso dependerá. Formá-los(as) para a autonomia responsável é nossa tarefa, mais que isso, é um imperativo ético, dado que a autonomia,

enquanto amadurecimento do ser para si, é processo, é vir a ser. Não ocorre em data marcada. É neste sentido que uma pedagogia da autonomia tem de estar centrada em experiências estimuladoras da decisão e da responsabilidade, vale dizer, em experiências respeitosas da liberdade. (Freire, 1996, p. 121)

Da educação tradicional ou bancária para uma educação democrática, progressista e libertadora, como queria Freire, há um largo espaço a ser transposto. Formada que fui, desde os primeiros passos, com a marca da primeira forma de educação, tornar-me uma professora democrática custou-me (e ainda custa) um exercício constante de revisão de meus atos didático-pedagógicos.

O diálogo respeitoso, preconizado por Freire ao longo de toda sua obra, fruto de uma relação horizontal desenvolvida em sala de aula, foi o motor dessa 
mudança. Ouvir os(as) alunos(as), gentil e pacientemente, dando-lhes voz ao longo de todo o processo, fez toda a diferença. Todos(as) devem se expressar e a todos(as) o respeito a essa expressão de opiniões, vontades e questionamentos é devido. Mas não o diálogo convertido em "bate-papo desobrigado que marche ao gosto do acaso entre professor ou professora e educandos" (Freire, 2000, p. 118), mas sim, o diálogo visto como possibilidade de verdadeiro encontro. Para Freire (1969/2013b),

O que se pretende com o diálogo, em qualquer hipótese, ... é a problematização do próprio conhecimento em sua indiscutível reação com a realidade concreta na qual se gera e sobre a qual incide, para melhor compreendê-la, explicá-la, transformá-la. (p. 52)

E, se em sala de aula, o clima de respeito aos saberes e dizeres tanto de alunos(as) quanto de professores(as) se estabelece, todos(as) compreenderão a importância da aceitação do(a) outro(a) sem discriminação de qualquer espécie. Com lucidez, Freire afirmou que "qualquer discriminação é imoral e lutar contra ela é um dever por mais que se reconheça a força dos condicionantes a enfrentar” (Freire, 1996, p. 68). Ao (À) professor(a) de opção democrática caberá sempre imprimir um clima de aceitação e respeito em sala de aula, a partir de suas próprias ações igualmente respeitosas.

Ao longo dos meus muitos anos de docência em cursos, palestras e encontros voltados para a formação de professores(as), sempre me perguntei qual o meu propósito, como educadora, naquele tempo e naqueles espaços. Faria algum sentido para aqueles(as) que me ouviam o recado que eu lhes trazia? O que me apontava - e ainda aponta - para a esperança de acertar era o que os ensinamentos de Freire me diziam, que inquietar o educando seria, de fato, nossa principal tarefa. Orientar suas dúvidas a que este sempre juntará

mais dúvidas, e, de maneira aberta, amiga, ora quietar, ora inquietar o [... educando]. Aquietar com resposta segura, com sugestão oportuna, com bibliografia necessária, que o levarão contudo a nova inquietação. A quietude não pode ser um estado permanente. Só na relação com a inquietude é que a quietude tem sentido. (Freire, 2003, pp. 215-216)

Se vivo, Paulo Freire completaria, no dia 19 de setembro próximo, 100 anos. Um momento para ser marcado com sua presença, apesar de sua morte em 1997.

Sem Paulo Freire há 24 anos, o que mudou na educação de nosso país? Muito pouco! Realmente muito pouco! 
A educação brasileira continua ofertada de maneira desigual para ricos e pobres. A qualidade da educação como um todo ainda deixa a desejar, mas para os socialmente excluídos(as), aqueles(as) oprimidos por uma estrutura econômica e social absolutamente perversa, a desigualdade acentua a precariedade dos meios e a eficiência dos fins. O descaso com relação a essa problemática, descaso absolutamente intencional, segue reproduzindo injustiças. Ainda hoje temos analfabetos no país: 11 milhões! ${ }^{18}$ Se somarmos a esse número os analfabetos funcionais (aqueles que têm dificuldades para interpretar textos lidos e/ou realizar operações matemáticas simples) chegaremos a $29 \%$ da população (Indicador de Alfabetismo Funcional, 2018)!

Cerca de $30 \%$ da população brasileira não tem, portanto, sequer as condições mínimas de exercerem plenamente a cidadania à qual têm direito!

Mas não sou uma educadora desesperançada. Na esperança, como bem dizia Freire (2000), espero fazer o meu melhor para todos(as) aqueles(as) de quem minha honrosa profissão me aproxima. E eu espero dias melhores, mas "eu espero na medida em que começo a busca, pois não seria possível buscar sem esperança" (p. 29), sabendo, no entanto, "que não há esperança na pura espera, nem tampouco se alcança o que se espera na espera pura, que vira, assim, espera vã” (p. 11). Penso que nossa esperança não pode ser vã. Esperancemos pois.

\section{COMUNICAÇÃO PARA O DESENVOLVIMENTO NAS PEGADAS DE PAULO FREIRE}

\author{
MARIA SALETT TAUK SANTOS \\ Universidade Federal Rural de Pernambuco, Programa de Pós-Graduação em Consumo e \\ Desenvolvimento Social. Recife - PE, Brasil
}

As ideias de Paulo Freire constituem um divisor de águas entre a corrente do pensamento comunicacional que defende a modernização como pretensa saída para promover o desenvolvimento rural e a corrente teórica da comunicação dialógica construída a partir do seu pensamento.

O modelo de comunicação para o desenvolvimento, na versão da Extensão Rural/Comunicação Rural, implantado no Brasil nos anos de 1940, objetivava viabilizar a política modernizadora do campo a partir do modelo difusionista vindo das universidades de Wiscosin e Michigan, e com o apoio de organizações internacionais a exemplo da Fundação Ford, a Fundação Rockfeller e a Fundação Kellog’s (Tauk Santos, 1994), através de um sistema
${ }^{18}$ Taxa de analfabetismo no Brasil: 6,6\%, em 2019 (Pnad, 2020).

${ }^{s}$ Professora titular da Universidade Federal Rural de Pernambuco e coordenadora do Programa de PósGraduação em Extensão Rural e Desenvolvimento Local da UFRPE. Orcid: https://orcid. org/0000-0002-4802-0997. E-mail: mstauk@hotmail.com 
capitaneado pela Associação Brasileira de Assistência Técnica e Extensão Rural (ABCAR, depois Embrater - Empresa Brasileira de Assistência Técnica e Extensão Rural), o governo brasileiro cria um sistema de Comunicação Rural, segundo preceitos do manual Planejamento do Trabalho em Extensão Agrícola, de Timmer (1954), que recomenda "persuadir as populações rurais a aceitar a nossa propaganda”. Referia-se às informações tecnológicas que as populações rurais deveriam incorporar para produzir as mudanças sociais pretendidas com vistas à modernização do campo. A noção de mudança, dentro do modelo difusionista da Comunicação Rural era, portanto, a de um processo induzido, planejado de fora para dentro do meio onde deveria acontecer.

A crítica mais fecunda a este modelo foi a de Paulo Freire (1969/2013b) no seu livro Extensão ou Comunicação?. Retrucando a postura persuasiva inerente ao modelo difusionista, Freire afirma: “a nós não nos é possível persuadir e aceitarmos a persuasão como ação educativa... Nem aos camponeses, nem a ninguém se persuade ou se submete à força mítica da propaganda quando se tem uma ação libertadora” (p. 23). "Opção libertadora” compreendida como a problematização de situação concreta dos homens para que eles para que eles, captando a sua realidade de maneira crítica sejam capazes de desenvolver ações para transformá-la (Freire, 1969/2013b).

O pensamento filosófico freiriano, nos anos de 1970, se espraia por toda a América Latina, um continente oprimido pelas ditaduras militares, pelo imperialismo econômico e cultural, e pela opressão vivida pelos operários e camponeses, nas mãos das elites econômicas do País (Tauk Santos, 2002).

A flexibilização dos regimes autoritários nos anos de 1980 favoreceu a disseminação da teoria de Freire nos campos da educação e da comunicação. É nesse cenário que, ao ingressar como docente no Departamento de Educação da Universidade Federal Rural de Pernambuco, em 1984, inicia, sob a inspiração dos aportes teóricos de Paulo Freire, nas obras Pedagogia do Oprimido (1968/2015); Educação como prática da liberdade (1999); e Extensão ou Comunicação? (1969/2013b) um trabalho de extensão e de pesquisa acadêmica em Comunicação para o Desenvolvimento.

Trago, a seguir, breves relatos de algumas dessas experiências acadêmicas vividas na docência em cursos de Graduação e Pós-graduação em Comunicação e nas Ciências Agrárias. Experiências que realizei com o auxílio de uma constelação de autores, mantendo, entretanto, matrizes fundamentais do pensamento de Paulo Freire: a opção pelo trabalho com as culturas populares numa postura crítica; a valorização do saber e do diálogo com homens, mulheres e jovens do campo; e o apoio às formas de luta, organização e participação populares: 
Comunicação, Igreja Católica e participação dos agricultores familiares

- análise da pedagogia problematizadora para estimular a participação e a luta no campo (Tauk Santos, 1992);

Ação em assentamento de reforma agrária

- apoio político e assessoria técnica à população assentada no Engenho Pitanga - PE (Tauk Santos \& Callou, 1993);

Agricultura de base agroecológica

- estímulo à participação na luta por políticas favoráveis à agricultura familiar (Tauk Santos, 1994);

Comunidades pesqueiras artesanais

- ações para a construção do desenvolvimento local na Ilha de Deus, PE (Tauk Santos, Callou, et al., 2009);

Mulheres pescadoras artesanais

- análise do lazer e o consumo cultural das mulheres na pesca artesanal (Tauk Santos, Fox, et al., 2009);

Inclusão digital

- pesquisa das políticas de inclusão digital na perspectiva da inclusão social em contextos populares (Tauk Santos, 2009);

Desenvolvimento local e cidadania na gestão municipal

- análise dos desafios e estratégias de comunicação participativa da Prefeitura de Camaragibe (Tauk Santos, 2014a);

Mídias e culturas populares

- análise do papel do rádio na construção da democracia participativa na cidade (Tauk Santos, 2014b);

- análise do compromisso da mídia televisiva com as populações e com as comunidades locais (Tauk Santos, 2013);

Economia criativa e contextos populares

- análise das apropriações das políticas de economia criativa pelos jovens da Bomba do Hemetério, periferia do Recife (Tauk Santos et al., 2019).

Os resultados de como a matriz teórica de Paulo Freire repercutiu na formação dos alunos do Programa de Pós-Graduação em Administração Rural e Comunicação Rural; do Programa de Pós-Graduação em Extensão Rural e Desenvolvimento Local e do Programa de Pós-Graduação em Consumo e Desenvolvimento Social, da Universidade Federal Rural de Pernambuco, encontra-se nas mais de 1000 páginas do livro Travessias Acadêmicas das Tecnologias da Comunicação para o Desenvolvimento (Tauk Santos \& Callou, 2019).

A abertura da obra traz um texto inédito de Paulo Freire (2019), "A Educação como Espanto". Um tributo amoroso às pegadas deste educador que inspirou as nossas travessias acadêmicas. 


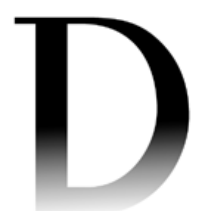

Professora na Universidade Presbiteriana Mackenzie. Orcid: https://orcid.org/00000002-4317-0793. E-mail: marisa.lajolo@mackenzie.br

\section{PAULO FREIRE EM CAMBRIDGE E NA UNICAMP}

\author{
MARISA LAJOLOt \\ Universidade Presbiteriana Mackenzie, Centro de Comunicação e Letras. São Paulo - SP, Brasil
}

Tão cedo passa tudo quanto passa! -Fernando Pessoa. Odes de Ricardo Reis.

A mais antiga lembrança que tenho de Paulo Freire não é dele em carne o osso. É dele na voz da Vera Queiroga, uma companheira da república onde morávamos, a Casa da Universitária, na rua Abílio Soares. Início da década de 1960, éramos vinte quatro moças do interior, que estudavam em São Paulo. Eu fazia Letras e a Vera, Pedagogia.

Ela participava de um projeto de educação de adultos desenvolvido na Vila Helena Maria em Osasco e contava, entusiasmada, de um educador nordestino que tinha ideias completamente originais sobre educação. Ele chamava-se Paulo e eram dele as ideias que animavam e norteavam o projeto de que minha colega participava.

O tempo foi passando, chegou o golpe de 1964. Projetos de educação popular foram cancelados, os educadores que deles participavam foram perseguidos. A república estudantil ficou no passado. Mas não se apagou no passado a imagem de Paulo, aquele educador nordestino de que falava Vera. Perseguido pela ditadura, ele tinha sido preso e, depois, se exilado no Chile.

Eu me casei com o Franco e a Vera casou-se com o Zé Carlos - que chamávamos de Barretão. Ele também participava do projeto de educação de adultos, e também era entusiasta da pedagogia freiriana, que... Naquele tempo, não se chamava assim.

Depois de casada, morei por um tempo em Boston.

Foi lá, cidade de muita neve e lindos prédios de tijolinhos vermelhos, que fiquei conhecendo, em carne e osso, o educador nordestino de que Vera e Barreto falavam com tanto entusiasmo.

Paulo Freire foi convidado como professor visitante pela Universidade de Harvard. Chegou com a família: a esposa dona Elza e os filhos. A notícia correu na comunidade de brasileiros. Quando fiquei sabendo, me lembrei das referências que minha colega fazia a ele. A cidade - particularmente Cambridge, onde fica a Universidade de Harvard - fervia com movimentos políticos: Black Panthers e feministas, passeatas de oposição à Guerra do Vietnã. 
A anunciada vinda de Paulo Freire - o orgulho por um patrício perseguido em sua terra, professor visitante de uma das mais prestigiadas universidades do mundo! - mexeu com a comunidade brasileira. A mim, particularmente, me envolveu numa nuvem de recordações. Por onde andariam a Vera e o Barretão? Será que eu ia encontrar Paulo Freire? Torcia que sim.

Dei sorte.

Encontrei-o numa palestra em Harvard: um punhado de brasileiros, junto com gente de todos os cantos do planeta, foi à universidade ouvir aquele educador que tinha ideias originais - e mais do que isso, revolucionárias - sobre educação.

Casa cheia: pelo que me recordo, o tema da conferência era Educação Popular.

Magro e barbudo, muito calmo, começou explicando que falaria em português. Um jovem, a seu lado, fazia a tradução. Na fala de Paulo, me maravilharam, por um lado, certas construções retóricas, observações entusiasmadas sobre suas experiências; de outro, o tom de intimidade com que alinhavava suas reflexões sobre o direito à educação e a importância de saber ler e escrever.

Depois da palestra procurei-o. Apresentei-me como colega da Vera e do Barreto. Ele me informou da sua sala na universidade.

Fui vê-lo, emocionadíssima.

E ficamos amigos para sempre...

Me impressionava muito o que Paulo contava sobre sua experiência de viver em um país estrangeiro. Contava que o espanhol do Chile era menos estrangeiro do que o inglês de Cambridge. Foi nestas conversas, absolutamente informais que aprendi a profunda relação que Paulo estabelecia entre linguagem e vida, entre linguagem e mundo. Comecei a entender que suas propostas de alfabetização - que vou resumir na expressão freiriana leitura do mundo - decorriam da íntima relação que ele estabelecia entre linguagem e vida.

Acompanhei algumas vezes dona Elza ao mercado. Entre compras, fiquei sabendo da saudade da família da comida brasileira. E de como Paulo era desligado da vida doméstica.

Paulo deixou Cambridge. E se foi para a Suíça.

O pós-doutorado do Franco acabou e voltamos ao Brasil.

De novo, o tempo passou. Mais ou menos dez anos depois, reencontrei Paulo na Unicamp. Ele, na Faculdade de Educação, eu, no Instituto de Estudos da Linguagem. As conversas retornaram, na paisagem da via Anhanguera e da Bandeirantes, estradas que unem São Paulo e Campinas. Paulo me dava carona, e Bernardo (seria esse mesmo o nome?) era o competente e bem-humorado motorista do carro, todo decorado com objetos que lembravam o nordeste... 
Paulo me perguntava sobre leituras populares. Afinal, seu trabalho era prioritariamente voltado pera educação popular. E eu não tinha como responder. Não tinha ideia do que se lia para fora do restrito círculo do povo das letras. Um dia, Paulo pediu que eu organizasse uma apostila com textos literários que eu considerasse adequados para leitores com pouca familiaridade com a escrita.

Pensei muito. Conversei com colegas. No fim, decidi por poemas. Por hipótese, curtos. Ainda por hipótese, rítmicos, próximos da oralidade. Alguns, poemas de amor, e outros do que hoje eu chamaria de textos militantes. De repente, veio uma ideia. Resolvi incluir um poema concreto, meio vanguarda da época: poema cujos versos não seguiam a linearidade tradicional da língua escrita. Algumas palavras tinham letras que escorriam na vertical.

Entreguei para o Paulo. Algumas semanas depois, ele me disse que o poema concreto foi o texto de que os alunos mais gostaram.

Fiquei perplexa.

Paulo explicou que os alunos gostaram do poema porque parecia com a escrita dos ônibus, onde às vezes o ponto final vinha escrito de pé e não deitado.

...grande lição, vinda de uma sala de educação de adultos, naquela manhã a caminho da universidade...

Além de conversas de estrada, alguns jantares: na casa dele ou na minha onde, sempre, o eterno macarrão - único prato que tenho coragem de servir aos amigos! - era infalivelmente acompanhado de uma autêntica cachaça pernambucana.

Quanta saudade...

\section{MEUS ENCONTROS COM PAULO FREIRE}

"Professor do Programa de Pós-graduação em Educação da Universidade de Caxias do Sul, possui doutorado em História e Sociologia da Educação pela Universidade de São Paulo. Orcid: https://orcid.org/00000002-6243-1813. E-mail: shaddad@ucs.br

\author{
SÉRGIO HA D D A D " \\ Universidade de Caxias do Sul, Programa de Pós-graduação em Educação. Caxias do Sul - RS, Brasil
}

Meu primeiro contato com a obra de Paulo Freire foi em 1967, ainda como secundarista, na casa do então deputado federal Franco Montoro. Ali, junto com um grupo de colegas, participei de um curso sobre o método de alfabetização desenvolvido pelo educador, etapa preparatória para uma ação dirigida a jovens e adultos que viviam em uma comunidade próxima da escola onde estudava. Já tínhamos, naquele momento, acesso ao seu livro Educação como Prática da Liberdade (Freire, 1999).

Paulo Freire já não vivia mais do Brasil, estava exilado em Santiago, no Chile, com sua esposa e cinco filhos, em razão do golpe civil-militar de 1964, que o 
perseguiu no momento em que coordenava desde Brasília as ações preparatórias do Programa Nacional de Alfabetização a ser lançada presidente João Goulart. Um ano antes, em 1963, uma experiência de alfabetização com quarenta trabalhadores rurais em Angicos, no Rio Grande do Norte, faria de Paulo Freire uma referência nacional. Seu método alfabetizava em 40 horas e o fazia ampliando a consciência dos trabalhadores sobre seus problemas, buscando as causas e discutindo soluções que estivessem ao seu alcance para superá-los. Um método assim, com tais características, implantado nacionalmente, não só colocaria milhões de pessoas em condições de votar, em uma sociedade em que o analfabetismo era uma barreira para a obtenção desta condição, como as colocaria de uma forma muito mais consciente dos seus problemas, ameaçando os tradicionais currais eleitorais. Para o grupo civil-militar que assumiu o poder, seria uma ameaça à estabilidade política, resultando na sua prisão e posteriormente no exílio.

Anos mais tarde, em 1974, assumi a coordenação de um Curso Supletivo, na mesma escola em que havia estudado e realizado, como aluno, a experiência de alfabetização mencionada anteriormente. O desafio do curso, voltado para jovens e adultos que não haviam completado a sua escolaridade básica, era muito grande. Paulo Freire voltou a ser referência para o grupo de jovens professores e professoras, muitos recém-formados, que assumiram aquela responsabilidade. Estávamos no período mais difícil da ditadura militar e víamos naquele curso, numa perspectiva freiriana, uma oportunidade de trabalho político e educacional com pessoas trabalhadoras de setores populares.

Paulo Freire não estava mais no Chile. Depois de passar um ano nos Estados Unidos, na Universidade de Harvard, vivia em Genebra, na Suíça, desde 1970, quando assumiu o departamento de educação do Conselho Mundial das Igrejas. Já havia escrito Pedagogia do Oprimido (Freire, 1968/2015), que viria a se tornar sua obra de maior reconhecimento mundial, traduzida para mais de 20 línguas, inacessível aos brasileiros, assim como vários outros textos, em razão da perseguição política. Obtínhamos seus escritos por meio de cópias ou publicações de outros países, em particular do Uruguai e Argentina. Serviram para orientar nosso trabalho, reconhecendo que os estudantes eram portadores de conhecimentos próprios e de histórias de vida que deveriam ser considerados nos processos de aprender e ensinar coletivos. Aprendemos com ele que deveríamos ser coerentes com nossos programas de estudos que falavam sobre democracia e liberdade de expressão, exercendo tais valores também em nossas metodologias e práticas. Aprendemos a respeitar as culturas diversas de uma sala de aula formada por pessoas vindas de diversos locais e que viviam na cidade de São Paulo.

No final dos anos 1970 e primeiros anos de 1980, o pensamento freiriano alimentava os trabalhos de educação popular, aqueles realizados nos espaços 
não escolares, nas Comunidades Eclesiais de Base (CEBS), nos movimentos populares de luta por moradia, creche, carestia, nos sindicatos. Naqueles anos, combinava meu trabalho no curso supletivo com o de uma organização não governamental chamada Centro Ecumênico de Documentação e Informação (CEDI), fundada por um grupo de ativistas, de maioria protestante, para assessorar o trabalho de base das CEBS. Mergulhei nestas assessorias, com Paulo Freire debaixo do braço, trabalhando com pesquisa participante em Goiás Velho e alfabetização de adultos com seringueiros no Acre, a pedido de Chico Mendes, e na região do rio Solimões, a pedido do Movimento de Educação de Base (MEB) da Conferência Nacional dos Bispos do Brasil (CNBB). Paulo Freire, seu pensamento e método de alfabetização foram as bases do trabalho realizado.

No retorno definitivo ao Brasil, em 1980, o educador passou a viver em São Paulo para trabalhar na Pontifícia Universidade Católica de São Paulo (PUCSP) e, posteriormente, na Universidade Estadual de Campinas (Unicamp). Era uma pessoa conhecida internacionalmente, tendo feito mais de 150 viagens internacionais para diversos países de todos os continentes. Continuou atendendo aos convites para trabalhos no exterior, mas agora também no Brasil, sedento que estava por se atualizar sobre a realidade brasileira. Suas obras já eram publicadas regularmente no país e tornaram-se de fácil acesso.

Foi no seu retorno do exílio que o conheci pessoalmente como colega na PUCSP, local onde comecei a dar aulas depois que deixei a coordenação do curso de adultos. Troquei com Paulo Freire conversas sobre o meu trabalho, algumas vezes em sua residência, para discutir e pedir o seu apoio, sempre atendido, apesar da sua agenda lotada.

Em 1987, me candidatei a um posto no Conselho Mundial de Igrejas como Secretário Executivo do Programa de Educação Básica de Adultos. Para fundamentar o meu processo, pedi cartas de recomendação, uma delas para Paulo Freire, que prontamente me atendeu, escrevendo no final do seu texto: "Being a member of the staff of the WCC, for 10 years, I am pleased to strongly recommend Mr. Haddad...He seems a 'right person' for this position, at this moment of his personal history". Guardo até hoje sua carta como recordação da sua generosidade.

Quando Paulo Freire assumiu a Secretaria de Educação do Município de São Paulo, no governo da prefeita Luiza Erundina, em 1979, ele me convidou para assumir a responsabilidade pela educação de adultos no município. Infelizmente não tive condições de aceitar, mas fiquei lisonjeado pelo convite e confiança.

Paulo Freire sempre foi uma referência para mim como ativista social, trabalhando com educação popular no CEDI e, desde 1994, na Ação Educativa. Minhas pesquisas no mestrado e no doutorado e, posteriormente, como pesquisador do CNPq ou Fapesp, foram no campo da educação de adultos e 
sobre seu pensamento. A última delas, cujos resultados foram publicados no e-book Grundtvig e Freire: Escolas Populares na Dinamarca e no Brasil (Haddad et al., 2020), que introduz ao público brasileiro as ideias pedagógicas do pensador dinamarquês Nikolaj F. S. Grundtvig em comparação com as de Paulo Freire.

Frente a este histórico, tomei a decisão de dedicar dois anos para reler suas obras, ler o que não havia lido, entrevistar pessoas, pesquisar em jornais, revistas e artigos sobre Paulo Freire e, finalmente, escrever o livro O Educador: Um Perfil de Paulo Freire (Haddad, 2019). Nele, traço um perfil biográfico, procurando, em linguagem literária e menos acadêmica, contar a sua história, falando da sua vida, da conjuntura nos lugares por onde morou no exílio, sobre seu pensamento e obras. Escrevi na apresentação que os objetivos do livro eram de duas naturezas: uma conjuntural e outra pessoal. A conjuntural alertava para o momento de ataques e defesas do seu legado, espelho da polarização política em que estava dividida a sociedade brasileira, por vezes um debate desinformado sobre o educador e a sua obra. O livro pretendeu cobrir essa lacuna, oferecendo um texto que fosse porta de entrada para um entendimento mais aprofundado sobre o biografado. O objetivo de natureza pessoal foi o prestar uma homenagem a quem me acompanhou como educador e ativista social ao longo da minha trajetória pessoal e profissional. $\mathbf{M}$

\section{REFERÊNCIAS}

Alfonso, H. (2000). Socially shared inquiry: A self-reflexive, emancipatory, communication approach to social research. Great Books Trading.

Amoyan C. J., \& Custodio, P. A. (2019). Development communication and the dialogic space: Finding the voices under the mines. In M. Dutta \& D. Zapata (Eds.), Communicating for social change (pp. 63-85). Palgrave Macmillan. https://doi.org/10.1007/978-981-13-2005-7_4

Arendt, H. (1970). On violence. Harcourt, Brace \& Co.

Baurile, L. M. B. (2014) E Kasi Bata: Indoctrination of youth in Philippine politics. [Trabalho de conclusão de curso não publicado]. College of Development Communication, University of the Philippines Los Baños.

Chiappini, L. (Coord.). (2015). Coleção Aprender e ensinar com textos (7a ed.). Cortez.

Citelli, A. O., Soares, I. de O., \& Lopes, M. I. V. de. (2019). Educomunicação: Referências para uma construção metodológica. Comunicação \& Educação, 24(2), 12-25. https://doi.org/10.11606/issn.2316-9125.v24i2p12-25

Dagli, W. (2018, 20-24 June). Communication for social change: A view from Devcom Los Baños [Artigo apresentado]. 2018 Annual Conference of the International Association of Media and Communication Research (IAMCR), University of Oregon, Eugene, OR, USA. 
Dahl, R. (1957). The concept of power. John Wiley \& Sons.

Daya, R. (2010). Experiences of facilitators in using ADIDS as a participatory approach in a training class: an exploratory study. USM R\&D, 18(2), 171-180. https://bit.ly/3G7l5kt

Dussel, E. \& Apel, K.-O. (2013). ética del discurso y ética de la liberación. Editorial Docencia.

Flor, A. G. (2004). Environmental Communication: Principles, Approaches and Strategies of Communication Applied to Environmental Management. University of the Philippines Open University.

Freire, A. M. A. (2017). Paulo Freire: Uma história de vida. Paz \& Terra.

Freire, P. (1970a). Pedagogy of the oppressed. Continuum.

Freire, P. (1970b). Pedagogy of the oppressed. Bloomsbury.

Freire, P. (1970c). Pedagogy of the oppressed. Herder and Herder.

Freire, P. (1983). Educação e mudança (7a ed.). Paz e Terra.

Freire, P. (1996). Pedagogia da autonomia: Saberes necessários à prática educativa. Paz e Terra.

Freire, P. (1999). Educação como prática de liberdade. Paz e Terra.

Freire, P. (2000). Pedagogia da esperança (7a ed.). Paz e Terra.

Freire, P. (2003). Cartas a Cristina: Reflexões sobre minha vida e minha práxis (2a ed.). Unesp.

Freire, P. (2012) Por uma pedagogia da pergunta (10a ed.). Paz e Terra.

Freire, P. (2013a). Ação cultural para a liberdade e outros escritos (16a ed.). Paz \& Terra (Trabalho original publicado em 1976).

Freire, P. (2013b). Extensão ou comunicação? (18a ed.). Paz \& Terra. (Trabalho original publicado em 1969)

Freire, P. (2015). Pedagogia do oprimido (59a ed.). Paz e Terra. (Trabalho original publicado em 1968).

Guanio. K. R. (2017). Emerging and shifting: Power and the organic participatory development communication of the autism recovery network of the Philippines $(A R N P)$ within the autism community in Camarines Norte [Trabalho de conclusão de curso não publicado]. University of the Philippines Los Baños.

Haddad, S. (2019). O educador: Um perfil de Paulo Freire. Todavia.

Haddad, S. (Org.). (2020). Grundtvig e Freire: Escolas populares na Dinamarca e no Brasil. Ação Educativa. https://doi.org/10.29327/527607

Hemingway, E. (1940). For whom the bell tolls [Por quem os sinos dobram]. Charles Scribner's Sons.

Hesse, H. (2012). Demian (44a ed.). Record. (Trabalho original publicado em 1919).

Indicador de Alfabetismo Funcional (Inaf). (2018). Alfabetismo no Brasil. https://bit.ly/37ihCQD 
Jallov, B. (1982). Et modbillede i lyd. En metode for frigørende radioproduktion for kvinder [Dissertação de mestrado não publicada]. Roskilde Universitet. Jallov, B. (2014). Community participation and communication support programme: Midterm evaluation. Government of the Lao PDR, United Nations Development Programme Country: Lao PDR. https://bit.ly/3ldKxOf

Jallov, B. (2015). Community radio and community multimedia centres in Mozambique: A brief history. EMPOWERHOUSE. https://bit.ly/3fg6acV

Leite, L. C. M. (2005). Encontro com Paulo Freire. In: Reinvenção da catedral: Literatura e ensino em debate (pp. 302-326). Cortez Editora.

Libanio Christo, C. A. (2021). Homage to Paulo Freire on his centenary [vídeo]. Loughborough University. https://doi.org/10.17028/rd.lboro.14398010.v1

Negt, O. (1971). Soziologische Phantasie und exemplarisches Lernen. Europäische Verlagsanstalt. EVA.

O'Connor, J. (2020, 11 de fevereiro). "Bombies": Legacies of the secret war in Laos. LSE International History. https://bit.ly/3yiKqo7

Pereira Coelho, E. (2011). Pedagogia da correspondência, Paulo Freire e a educação por cartas e livros. Liber Livros.

Pnad. (2020). Pesquisa Nacional por Amostra de Domicílios Contínua: Educação 2019. https://bit.ly/37ihArZ

Quebral, N. C. (1971, 9-10 de dezembro). Development communication in the agricultural context [Paper presentation]. Symposium on the theme "In search of breakthroughs in agricultural development" held in honour of Dr. Dioscoro Umali, College of Development Communication, Los Baños - Laguna, Filipinas.

Quebral, N. C. (2012). Development communication primer. Southbound.

Russell, B. (1916). Principles of social reconstruction. Allen and Unwin.

Saul, A. M. (2017). Ensino e pesquisa na PUC-SP marcam 20 anos de presença/ ausência de Paulo Freire. Reflexão e Ação, 25(2), 119-133. http://dx.doi.org/ 10.17058/rea.v25i2.8962

Smith, M. K. (2002). Paulo Freire and informal education. The encyclopedia of pedagogy and informal education. https://bit.ly/3xcNpgv (Trabalho original publicado em 1997)

Tauk Santos M. S., \& Callou, A. B. F. (1993). Alternativas de comunicação rural e participação popular. In G. M. Braga \& M. K. Kunsch (Orgs.), Comunicação rural: Discurso e prática (pp. 128-137). Imprensa Universitária UFV.

Tauk Santos, M. S. (1992). Grito da seca: A retórica da participação. UFRPE; Universidade de Sherbrooke.

Tauk Santos, M. S. (1994). Igreja e pequeno produtor rural: A comunicação participativa no Programa Cecapas/Serta [Tese de doutorado não publicada]. Universidade de São Paulo. 
Tauk Santos, M. S. (2002). Comunicação participativa e ação libertadora: marxismo e cristianismo combinados na teoria da comunicação dos anos 1970 e 1980. In J. M. Melo, M. C. Gobbi, \& W. L. Kunsch (Orgs.), Matrizes comunicacionais latino-americanas (pp. 199-219). Unesco; Unesp.

Tauk Santos, M. S. (2009). Inclusão digital, inclusão social? Bagaço.

Tauk Santos, M. S. (2013). Mídias e culturas populares contemporâneas: Mediação e tutela. Signos do Consumo, 5(1), 5-18. https://doi.org/10.11606/ issn.1984-5057.v5i1p5-18

Tauk Santos, M. S. (2014a). Desenvolvimento local e cidadania: Desafios e estratégias de comunicação da gestão participativa popular da prefeitura de Camaragibe PE. In A. B. F. Callou \& M. S. Tauk Santos, Extensão rural, extensão pesqueira: Estratégias de comunicação para o desenvolvimento (pp. 521-531). Fasa.

Tauk Santos, M. S. (2014b). Rádio comunidade: Construindo a democracia participativa na cidade. In A. B. F. Callou, \& M. S. Tauk Santos, Extensão rural, extensão pesqueira: Estratégias de comunicação para o desenvolvimento (pp. 285-297). Fasa.

Tauk Santos, M. S., \& Callou, A. B. F. (2019). Travessias acadêmicas das tecnologias da comunicação para o desenvolvimento (pp. 19-27). Fasa.

Tauk Santos, M. S., Barbosa, J. F. A., Camêlo, T. A., Sousa, A. L. M., \& Andrade, S. L. (2019). Muito além do folclore e da cibercultura: Economia criativa nas culturas populares. In M. S. Tauk Santos \& A. B. F. Callou, Travessias acadêmicas das tecnologias da comunicação para o desenvolvimento (pp. 299-306). Fasa.

Tauk Santos, M. S., Callou, A. B. F., Amorim, J. B. B.; Mesquita, G. e Vasconcelos, G.. (2009). Redes de comunicação e desenvolvimento local na Ilha de Deus. In M. S. Tauk Santos, A. B. F. Callou, \& V. R. F. Gehlen, Comunicação, gênero e cultura em comunidades pesqueiras contemporâneas (pp. 251-264). Fasa.

Tauk Santos, M. S., Fox, V. P. P., Alves, R. P., Lima, I. O., \& Silva, R. C. (2009). Lazer e consumo cultural de pescadoras artesanais. In M. S. Tauk Santos, A. B. F. Callou, \& V. R. F. Gehlen, Comunicação, gênero e cultura em comunidades pesqueiras contemporâneas (pp. 99-124). Fasa.

Timbreza, S. J. T. (2018). (Re)constructing empowerment in development communication: Social constructs of some alumni of the College of Development Communication regarding empowerment [Trabalho de conclusão de curso não publicado]. University of the Philippines Los Baños.

Timmer, J.W. (1954). Planejamento de trabalho em extensão agrícola. Ministério da agricultura - Serviço de informação agrícola.

Veyne, P. (1998). Como se escreve a história: Foucault revoluciona a história (4a ed.). UNB. 